\title{
Protecting Outstanding Underwater Cultural Heritage through the World Heritage Convention: The Titanic and Lusitania as World Heritage Sites
}

\author{
Josh B. Martin * \\ University of Exeter Law School, University of Exeter, United Kingdom
}

\begin{abstract}
Despite growing recognition of the global value of underwater cultural heritage $(\mathrm{UCH})$, along with intensified international efforts to ensure its protection, the possibility of its inscription on the World Heritage List has never been comprehensively examined. Arguing that the UNESCO 2001 Convention on the Protection of Underwater Cultural Heritage (UCH Convention) is not sufficient alone to protect globally outstanding wrecks, such as the Titanic and the Lusitania, this article examines in detail the many legal and practical challenges involved with listing such sites under the World Heritage Convention. By reviewing key international agreements such as the UCH Convention, World Heritage Convention, Law of the Sea Convention and the International Titanic Agreement, it draws the conclusion that it is the improved offshore management of UCH - through 'cultural' marine protected areas operating under the framework of the UCH Convention - which would open the possibility of nomination to the World Heritage List.
\end{abstract}

\section{Keywords}

underwater cultural heritage - world heritage - RMS Titanic - RMS Lusitania - marine protected areas

\section{The Need to Protect Underwater Cultural Heritage through the World Heritage Convention}

The time has come to seriously rethink the omission of outstanding underwater cultural heritage (UCH) from protection under the UNESCO 1972 Convention Concerning the Protection of World Cultural and Natural Heritage (World Heritage Convention). ${ }^{1}$ Despite growing recognition of the global value

\footnotetext{
${ }^{*}$ LLB, LLM, PgDip, Researcher and Teacher in International Law and Politics at the University of Exeter, Rennes Drive, EX4 4RJ, United Kingdom.

${ }^{1}$ UNESCO Convention Concerning the Protection of the World Cultural and Natural Heritage (Paris, 23 November 1972: in force 17 December 1975) 1037 UNTS 151 ("World Heritage Convention"); For the purposes of this paper, we adopt the definition of UCH used in the UNESCO Convention on the Protection of Underwater Cultural Heritage (Paris, 2 November 2001; in force 2 January 2009) 2562 UNTS 1 ("UCH Convention"), Art. 1(1):

'(a) "Underwater cultural heritage" means all traces of human existence having a cultural, historical or archaeological character which have been partially or totally under water, periodically or continuously, for at least 100 years such as:
} 
derived from $\mathrm{UCH}$, along with intensified international efforts to ensure its protection, there has been remarkably little research exploring the legal and practical challenges to this end. ${ }^{2}$ To begin with, there are many persuasive arguments in favour of inscribing outstanding $\mathrm{UCH}$, such as the world-famous shipwrecks of the RMS Titanic and RMS Lusitania, on the World Heritage List ("List"). First, there is the general argument that we must do more to preserve our submerged cultural record. The UNESCO 2001 Convention on the Protection of Underwater Cultural Heritage (UCH Convention) ${ }^{3}$ was created after mounting pressure from an increasingly vocal global community of UCH conservationists, who sought international recognition of the archaeological, cultural, historical and recreational value of submerged cultural heritage. ${ }^{4}$ This was particularly in response to ever-growing threats to this heritage from human activities, such as by looting, salvage, vandalism, uncontrolled tourism, pollution, fishing, construction, mining, dredging, and climate change, as well as non-anthropogenic pressures, such as erosion, underwater currents and natural disasters. ${ }^{5}$

To archaeologists and enthusiasts, wrecks often represent 'time capsules', containing an unrivalled record of the ship's passengers and crew, frozen in time. ${ }^{6}$ Depending on the physical, chemical and biological environment, many archaeological remains and wrecks may also be remarkably well preserved or relatively stabilised within their submerged environment. ${ }^{7}$ Many underwater sites also represent immense cultural and

(i) sites, structures, buildings, artefacts and human remains, together with their archaeological and natural context;

(ii) vessels, aircraft, other vehicles or any part thereof, their cargo or other contents, together with their archaeological and natural context; and

(iii) objects of prehistoric character.

(b) Pipelines and cables placed on the seabed shall not be considered as underwater cultural heritage.

(c) Installations other than pipelines and cables, placed on the seabed and still in use, shall not be considered as underwater cultural heritage.'

${ }^{2}$ See infra (nn 48-75).

${ }^{3}$ See UCH Convention (n 1).

${ }^{4}$ Council of Europe, The Underwater Cultural Heritage: Report of the Committee on Culture and Education (Strasbourg, 4 October 1978), Doc. 4200-E, available at http://assembly.coe.int/nw/xml/XRef/XrefXML2HTML-en.asp?fileid=14882\&lang=en, accessed 22 June 2017; PJ O'Keefe \& JAR Nafziger, 'The Draft Convention on the Protection of Underwater Cultural Heritage', (1994), 25(4) Ocean Development and International Law 391-418, at pp. 392-394; See generally on the UCH Convention, PJ O'Keefe, Shipwrecked Heritage: A Commentary on the UNESCO Convention on Underwater Cultural Heritage $\left(2^{\text {nd }}\right.$ ed., Institute of Art \& Law, Leicester, 2014)

${ }^{5} \mathrm{~S}$ Dromgoole, Underwater Cultural Heritage and International Law (Cambridge University Press, Cambridge, 2014), at pp. 1-7; R Grenier, D Nutley and I Cochran (eds), Underwater Cultural Heritage at Risk: Managing Natural and Human Impacts (International Council on Monuments and Sites (ICOMOS), Munich, 2006).

${ }^{6}$ A Bowen (ed), Underwater Archaeology: The NAS Guide to Principles and Practice (2 $2^{\text {nd }}$ ed., Nautical Archaeological Society and Wiley-Blackwell, Chichester, 2008), at pp. 16-17.

7 IA Ward, P Larcombe and P Veth, 'A new process-based model for wreck site formation', (1999), 26(5) Journal of Archaeological Science 561-570. For example, the discovery in 2016 of HMS Terror, from Franklin's ill-fated Northwest Passage voyage 168 years earlier, found his flagship in pristine condition (P Watson, 'Ship found in Arctic 168 years after doomed Northwest Passage attempt', available at http://www.theguardian.com/world/2016/ sep/12/hms-terror-wreck-found-arctic-nearly-170-years-northwest-passage-attempt, accessed 22 June 2017). 
human value, by connecting us with significant events or times in history. ${ }^{8}$ They are also often protected as venerated gravesites for those lost in war or tragic disasters. ${ }^{9}$ Preserved UCH can also provide significant recreational, economic or ecological value when utilised as underwater museums or parks, wreck diving trails, artificial reefs, or when preserved for long-term research. ${ }^{10}$ When considering universally significant wrecks, such as the Titanic and Lusitania, therefore, the global urgency in fully protecting and preserving such sites for future generations is especially acute.

The second argument in favour of including outstanding UCH sites on the List arises from the obligation incumbent on the World Heritage Committee ("Committee") - elected among States Parties on six-year terms and overseeing the administration of the World Heritage Convention ${ }^{11}$ - to adopt a 'representative, balanced and credible' World Heritage List. ${ }^{12}$ Such is the importance of this objective, that recently a growing number of reports have stressed the urgent need to remedy gaps on the List, especially regarding a concerning a lack of 'marine' sites. ${ }^{13}$ The World Heritage Marine Programme was therefore launched in 2005 with the explicit aim to drive up

\footnotetext{
${ }^{8}$ K Taylor, 'Cultural Heritage Management: A Possible Role for Charters and Principles in Asia', (2004), 10(5) International Journal of Heritage Studies 417-433, at pp. 426-427.

${ }^{9}$ M Jacobsson and J Klabbers, 'Rest in Peace? New Developments Concerning the Wreck of the M/S Estonia', (2000), 69(3) Nordic Journal of International Law 317-332; JR Harris, 'The Protection of Sunken Warships as Gravesites at Sea', (2001), 7(1) Ocean and Coastal Law Journal 75-130.

${ }^{10}$ A Firth, Social and Economic Benefits of Marine and Maritime Cultural Heritage, (Fjordr Ltd for Honor Frost Foundation, London, 2015).

${ }^{11}$ World Heritage Convention (n 1), Arts. 8-10.

12 Intergovernmental Committee for the Protection of World Cultural and Natural Heritage, Operational Guidelines for the Implementation of the World Heritage Convention (UNESCO, Paris, 26 October 2016) WHC.16/01 (“Operational Guidelines”), at paras. 54-60; World Heritage Committee, 'Expert Meeting on the "Global Strategy" and thematic studies for a representative World Heritage List' (UNESCO Headquarters, 20-22 June 1994), in World Heritage Committee, Convention Concerning the Protection of World Cultural and Natural Heritage, Eighteenth Session, Phuket, Thailand, 12-17 November 1994 (UNESCO, Paris, 13 October 1994) WHC-94/CONF.003/INF.6 ("1994 Global Strategy").

13 After the launch of the World Marine Heritage Programme in 2005 (n 14), the IUCN collaborated with the World Heritage Centre in developing the Bahrain Action Plan for Marine World Heritage, which intended to bolster the Marine Programme (D Laffoley and J Langley (eds), Bahrain Action Plan for Marine World Heritage: Identifying Priorities and enhancing the role of the World Heritage Convention in the IUCN-WCPA Marine Global Plan of Action for MPAs in our Oceans and Seas (IUCN, Gland, 2010)); This was vindicated in 2013 by a gap analysis by IUCN (A Abdulla, D Obura, B Bertzky and Y Shi (eds), Marine Natural Heritage and the World Heritage List: Interpretation of World Heritage criteria in marine systems, analysis of biogeographic representation of sites, and a roadmap for addressing gaps (IUCN, Gland, 2013); The gaps in marine protection, especially in the high seas, were also reported in M Spalding, Marine World Heritage: Toward a representative, balanced and credible World Heritage List (UNESCO, Paris, 2012); Furthermore, an external audit on the implementation of the Global Strategy noted insufficient progress on the representation of marine natural heritage (World Heritage Committee, 'INF.9A: Final report of the Audit of the Global Strategy and the PACT Initiative' in World Heritage Committee, Convention Concerning the Protection of World Cultural and Natural Heritage, Thirty-fifth Session, Paris, UNESCO Headquarters, 19-29 June 2011 (UNESCO, Paris, 27 May 2011), WHC-11/35.COM/INF.9A, available at http://whc.unesco.org/archive/2011/whc11-35com-IN F9Ae.pdf; accessed 7 September 2017).
} 
listings of a marine nature ${ }^{14}$ and, since then, the total area of marine space on the List has doubled. ${ }^{15}$

Nevertheless, notwithstanding this increase, the List continues to appear unbalanced and unrepresentative. Despite $70 \%$ of the "blue" planet's surface being ocean, only $4.7 \%$ of listed World Heritage Sites are classed as 'marine'. ${ }^{16}$ Furthermore, of these marine sites, $92 \%$ are 'natural' sites, $8 \%$ are regarded as 'mixed' (both cultural and natural) and, somewhat unsettlingly, $0 \%$ are 'cultural' sites. ${ }^{17}$ It is also noticeable that the justifications for listing these marine sites utilise a discernibly terrestrial, rather than submarine, perspective of site value, for example, by emphasising coastal features, seabirds, capture fisheries, mangroves and lagoons. ${ }^{18}$ Nevertheless, UCH can and does feature within some World Heritage Sites. ${ }^{19}$ However, this is usually either by pure coincidence (e.g., Great Barrier Reef or Robben Island), ${ }^{20}$ or by forming a minor and ancillary value of the site and not the principal value receiving protection (e.g., Central Zone of Angra do Heroismo, Red Bay Basque Whaling Station and Gros Morne National Park). ${ }^{21}$

\footnotetext{
${ }^{14}$ World Heritage Committee, Convention Concerning the Protection of World Cultural and Natural Heritage, Twenty-ninth session, Durban, South Africa, 10-17 July 2005 (UNESCO, Paris, 9 September 2005), Decision 29 COM 5.1, available at http://whc.unesco.org/archive/ 2005/whc05-29com-05e.pdf; accessed 7 September 2017

15 D Obura and B Bertzky, 'Marine Gaps on the World Heritage List' in R Casier and F Douvere (eds), The Future of the World Heritage Convention for Marine Conservation: Celebrating 10 years of the World Heritage Marine Programme (UNESCO, Paris, 2016) $87-$ 104, at pp. 90-91.

${ }^{16}$ Calculation based on 49 marine sites out of a total of 1,052 sites (as at time of writing); See list of marine sites at Marine World Heritage Programme website available at http://whc.unesco.org/en/marine-programme/; accessed 22 June 2017; See World Heritage List at World Heritage Committee website available at http://whc.unesco.org/en/list/; accessed 22 June 2017. See (n 13) for literature addressing gaps in marine sites.

${ }^{17}$ Ibid., World Heritage Marine Programme lists the 49 marine sites, noting that 45 are 'natural', 4 are 'mixed' and 0 are 'cultural'.

18 Obura and Bertzky (n 15) also report that the list of marine sites is over-representative of island groups and specific faunal species, suggesting further representation is needed of 'pelagic, deep-sea and cold-water ecosystems, less iconic taxonomic groups, and geological and oceanographic features.'

${ }^{19}$ AA Yusuf, 'Definition of Cultural Heritage' in F Francioni and F Lenzerini (eds), The 1972 World Heritage Convention: A Commentary (Oxford University Press, Oxford, 2008) 23-50, at p. 44.
}

20 UNESCO World Heritage List, 'Great Barrier Reef' (available at http://whc.unesco.org/en/list/154; accessed 22 June 2017); UNESCO World Heritage List, 'Robben Island' (http://whc.unesco.org/en/list/916; accessed 22 June 2017).

${ }^{21}$ World Heritage Committee, Convention Concerning the Protection of World Cultural and Natural Heritage, Twenty-second session, Kyoto, Japan 30 November - 5 December 1998 (UNESCO, Paris, 29 January 1999) WHC-98/CONF.203/18, available at http://whc.unesco. org/archive/repcom98.htm; accessed 7 September 2017, at VII.39, notes the existence of underwater heritage in the Central Zone of Angra do Heroismo in the Azores site; UNESCO World Heritage List, 'Red Bay Basque Whaling Station' (available at http://whc.unesco.org/en/list/1412; accessed 22 June 2017), 'includes ... underwater remains of vessels and whale bone deposits'; UNESCO World Heritage List, 'Gros Morne National Park' (available at http://whc.unesco.org/en/list/419; accessed 22 June 2017), features the wreckage of the SS Ethie; Another example is the Sri Lankan government's efforts to expand the historic Old Town of Galle (UNESCO World Heritage List, 'Old Town of Galle and its Fortification' (available at http://whc.unesco.org/en/list/451; accessed 22 June 2017)) to include many shipwrecks in the surrounding waters, to which the Committee decided that ' $[\mathrm{t}]$ here is no need to extend the boundaries . . . to include the maritime archaeological heritage, as this heritage is not considered representative of the values of the property. In 
Furthermore, in the terrestrial context, $77 \%$ of World Heritage Sites are pure 'cultural' sites, but in the marine environment that number is $0 \%{ }^{22}$ The World Heritage List is therefore looking decidedly unbalanced and unrepresentative. $^{23}$ It is also noteworthy that $0 \%$ of marine sites are in areas beyond national jurisdiction (ABNJ). ${ }^{24}$ In 2016, therefore, the Marine World Heritage Programme published a report exploring how we can begin listing sites beyond states' exclusive economic zones (EEZs). ${ }^{25}$ This is well timed considering the decision at the United Nations, in 2015, to also develop an international instrument to protect biodiversity in this same oceanic zone. ${ }^{26}$ Unfortunately, at least for the time being, 'cultural' heritage remains outside both discussions. ${ }^{27}$ A third argument, therefore, is that the timing to explore placing UCH on the List is particularly apposite. Especially when one considers the present work to protect offshore natural heritage,$^{28}$ the increasing recognition across the global community of the critical importance of the

addition, the protection of underwater heritage is already sufficiently provided for [by domestic legislation]' - World Heritage Committee, 'Item 7B of the Provisional Agenda: State of conservation of properties inscribed on the World Heritage List' in World Heritage Committee, Convention Concerning the Protection of World Cultural and Natural Heritage, Fortieth Session, Istanbul, Turkey, 10-20 July 2016 (UNESCO, Paris, 27 May 2016) $\mathrm{WHC} / 16 / 40 . \mathrm{COM} / 7 \mathrm{~B}$, available at http://whc.unesco.org/archive/2016/whc16-40com-7Ben.pdf; accessed 7 September 2017, at p. 79.

${ }^{22}$ See World Heritage Marine Programme list (n 16) and World Heritage List (n 16). At time of writing, the World Heritage List includes 814 'cultural' sites, 203 'natural' sites, and 35 'mixed' sites (1,052 total).

${ }^{23}$ See generally (n 13).

${ }^{24}$ D Laffoley and D Freestone, 'World Heritage in the High Seas: An Idea Whose Time Has Come' in R Casier and F Douvere (eds), The Future of the World Heritage Convention for Marine Conservation: Celebrating 10 years of the World Heritage Marine Programme (UNESCO, Paris, 2016) 123-136, at p. 124, 'It would seem amazing to many that the 1972 World Heritage Convention has yet to be applied to the other half of our world that we know as the open ocean'; Obura \& Bertzky (n 15), at p. 96.

${ }^{25}$ D Freestone, D Laffoley, F Douvere and T Badman, World Heritage in the High Seas: An Idea Whose Time Has Come (UNESCO, Paris, 2016).

26 The United Nations General Assembly established an Ad Hoc Open-ended Informal Working Group in 2004 to examine issues relating to the conservation and sustainable use of biodiversity beyond national jurisdiction ("BBNJ Working Group") (United Nations General Assembly, Resolution adopted by the General Assembly on 17 November 2004, Fifty-ninth session (United Nations, 4 February 2005) A/RES/59/24, available at http://www.un.org/en/ development/desa/population/migration/generalassembly/docs/globalcompact/A_RES_59_24. pdf; accessed 7 September 2017, at para. 73). Then, on 19 June 2015, the General Assembly followed the BBNJ Working Group's recommendation to form a preparatory committee on an 'international legally binding instrument' under the LOSC, which then began its work in March 2016 (United Nations General Assembly, Resolution adopted by the General Assembly on 19 June 2015, Sixty-ninth session (United Nations, 6 July 2015) A/RES/69/292), available at http://www.wpcouncil.org/wp-content/uploads/2016/06/7.10-UN-General-assemblyresolution.pdf; accessed 7 September 2017. Progress of the Preparatory Committee can be followed at http://www.un.org/depts/los/biodiversity/prepcom.htm (accessed 7 September 2017).

${ }^{27}$ Freestone et al. (n 25), at p. 24, 'While the research for potential [world heritage] in the High Seas has focused on natural marine features and ecosystems, nothing would prevent the identification of cultural sites at a later stage.'

${ }^{28}$ E.g., Laffoley and Freestone (n 24), at p. 124, declare the 'time has come to close this gap, so that recognition and celebration can be given to areas of Outstanding Universal Value in this other half of planet Earth.' 
oceans in the fight against climate change, ${ }^{29}$ as well as the urgent need for more effective cross-border planning and integrated management of ocean spaces. ${ }^{30}$ It is critical that any negotiated trade-offs between ecological and socioeconomic values, under such an integrated approach, do not to fail to take into account the value of public 'cultural goods'.

The fourth argument for why we urgently need to explore $\mathrm{UCH}$ as world heritage is the lack of existing protection for globally outstanding $\mathrm{UCH}$. One might be tempted to assume that $\mathrm{UCH}$ does not require inclusion on the List as it has its own dedicated international convention. However, this is incorrect. An equivalent would be excluding biodiversity from world heritage status on account of the United Nations 1992 Convention on Biological Diversity. ${ }^{31}$ Although the UCH Convention provides some additional protections for $\mathrm{UCH}$ - for example by carefully restricting private salvage, by strengthening the principle of in situ preservation as a 'first option', and by promoting the proper conservation, curation and archaeological management of heritage $^{32}$ - there are still numerous issues with the Convention. For example, it completely fails to inform states how they should police looting or, more critically, avoid incidental harm to $\mathrm{UCH}$ from offshore activities. ${ }^{33}$ Furthermore, there are questions about how effectively it will be implemented in practice, beyond being a hortatory commitment between states. ${ }^{34}$ In fact, it is the explicit intention of the World Heritage Convention to provide additional support to existing regulation. ${ }^{35}$ In that vein, a fifth argument is that although the UCH Convention is slowly growing its membership from among some key maritime states, it still only has 56 States Parties at the time of writing, ${ }^{36}$ whereas the World Heritage Convention has 193 States Parties, all engaged with its objectives and familiar with its workings. ${ }^{37}$

\footnotetext{
${ }^{29}$ E.g., Sustainable Development Goal 14 declares that each country shall seek to '[c]onserve and sustainably use the oceans, seas and marine resources for sustainable development' in United Nations General Assembly, Transforming our world: the 2030 Agenda for Sustainable Development, Seventieth Session (United Nations, 21 October 2015) A/RES/70/1, at p. 23.

${ }^{30} \mathrm{C}$ Ehler and F Douvere (eds), Marine Spatial Planning: a step-by-step approach toward ecosystem-based management, Intergovernmental Oceanographic Commission and Man and the Biosphere Programme, IOC Manual and Guides No. 53, ICAM Dossier No. 6 (UNESCO, Paris, 2009); Y Tanaka, A Dual Approach to Ocean Governance: The Cases of Zonal and Integrated Management in International Law of the Sea (Routledge, London, 2009).

${ }^{31}$ United Nations Convention on Biological Diversity (Rio de Janeiro, 5 June 1992; in force 29 December 1993) 1760 UNTS 79.

${ }^{32} \mathrm{UCH}$ Convention (n 1), Arts. 2(5), 2(7) and 4.

${ }^{33} \mathrm{UCH}$ Convention (n 1), Art. 5; Forrest states that Article 5 'provides too weak an obligation on states' in C Forrest, International Law and the Protection of Cultural Heritage (Routledge, London, 2011), at p. 339; Varmer also criticises this as a 'soft legal obligation' in O Varmer, 'Closing the Gaps in the Law Protecting Underwater Cultural Heritage on the Outer Continental Shelf’, (2014), 33(2) Stanford Environmental Law Journal 251-286, at p. 263.

${ }^{34}$ R Mackintosh, 'The 2001 UNESCO Convention for the Protection of the Underwater Cultural Heritage: Implementation and Enforcement in the Adriatic: HFF Grant Report', available at http://honorfrostfoundation.org/wp/wp-content/uploads/2017/05/The-2001UNESCO-CPUCH-Rob-MacKintosh-2016-Final-Report.pdf; accessed 22 June 2017.

${ }^{35}$ Operational Guidelines (n 12), at para. 97; Royal Swedish Academy of Sciences, 'How the World Heritage Convention Works', (1983), 12(3/4) Ambio 140-145, at p. 140; Para. 41 also refers to the UCH Convention as an instrument with which the World Heritage Convention should interact; UCH Convention (n 1), Preamble, also notes the Convention's aim to 'codify and progressively develop rules' protecting $\mathrm{UCH}$, including the World Heritage Convention.

36 For the full list of States Parties to the UCH Convention see http://www.unesco.org/eri/la/convention.asp?KO=13520\&order=alpha; accessed 22 June
} 
The sixth and final argument is the suitability of the World Heritage Convention itself for protecting globally outstanding $\mathrm{UCH}$. The very raison d'être of the Convention is to mobilise international cooperation and assistance in ensuring the security of the world's most universally significant heritage. ${ }^{38}$ Most of the stated aims of the Convention - from education and awareness, capacity building, research collaboration, international assistance, resource pooling, and state-to-state cooperation ${ }^{39}$ - are similar in aspiration to the $\mathrm{UCH}$ Convention. ${ }^{40}$ Furthermore, the World Heritage Convention has a proven track record in successfully achieving these objectives and with positively transforming listed sites. ${ }^{41}$ Many other aspects of the World Heritage Convention are also well aligned with the aims of the UCH Convention, including: a 'publicisation' of sites by removing them from private exploitation; ${ }^{42}$ a move towards sustainable management and a focus on preservation for future generations $;^{43}$ an international law against the criminal damage of world heritage; ${ }^{44}$ a Heritage in Danger List to coordinate the actions of stakeholders and States Parties; ${ }^{45}$ a World Heritage Fund to mobilise training and resources, particularly to those sites in danger; ${ }^{46}$ and, perhaps most important of all, a network of expertise to support stakeholders with the

2017; Notable states to recently join include Italy, Morocco and Argentina (2010), France and Belgium (2013), Algeria and South Africa (2015).

37 For the full list of States Parties see UNESCO website at http://whc.unesco.org/en/statesparties; accessed 22 June 2017; F Douvere and T Badman, 'The 1972 World Heritage Convention for ocean conservation: Past, present and future' in R Casier and F Douvere (eds), The Future of the World Heritage Convention for Marine Conservation: Celebrating 10 years of the World Heritage Marine Programme (UNESCO, Paris, 2016) 11 22 , at p. 20.

${ }^{38}$ Obura and Bertzky (n 15), at p. 94; Royal Swedish Academy of Sciences (n 35), at p. 140.

39 World Heritage Convention (n 1), Preamble and Arts. 6, 19-24, 27 and 28; Operational Guidelines (n 12), at paras. 211-222.

${ }^{40}$ UCH Convention (n 1), Preamble and Arts. 2(2), 6 and 19-21.

${ }^{41}$ UNESCO World Heritage List, 'Success Stories' at http://whc.unesco.org/en/107; accessed 22 June 2017.

42 E.g., Jeffery says that inscribing heritage on the World Heritage List 'can also bring potential restrictions on what site owners can do with their properties' in B Jeffery, 'World War II underwater cultural heritage sites in Truk Lagoon: Considering a case for World Heritage listing', (2004), 33(1) International Journal of Nautical Archaeology 106-121, at p. 114; O'Keefe (n 2) describes the 'publicization' of UCH under the UCH Convention, at p. 124.

43 Operational Guidelines (n 12), at para. 109; T Maarleveld, U Guérin and B Egger (eds), Manual for Activities directed at Underwater Cultural Heritage: Guidelines to the Annex of the UNESCO 2001 Convention (United Nations Educational, Scientific and Cultural Organization (UNESCO), Paris, 2013), at p. 25.

${ }^{44}$ E.g. Summary of the Judgment and Sentence in the case of The Prosecutor $v$. Ahmad Al Faqi Al Mahdi, International Criminal Court, ICC-01/12-01/15, available at https:/www.icccpi.int/CourtRecords/CR2016_07244.PDF; accessed 7 September 2017, at para. 80; UCH Convention (n 1), Art. 17.

${ }^{45}$ World Heritage Convention (n 1), Art. 11(4); Operational Guidelines (n 12), at paras. $177-$ 198; According to Obura and Bertzky (n 15) at p. 94, four marine sites have been on the List of World Heritage in Danger since 2004: Galápagos Islands (Ecuador, 2007-2010), Belize Barrier Reef Reserve System (Belize, 2009-present), East Rennell (Solomon Islands, 2013present), and the Everglades National Park (United States of America, 1993-2007 and 2010present).

${ }^{46}$ World Heritage Convention (n 1), Arts. 15-18; Operational Guidelines (n 12), at paras. 223 257. 
creation of world-leading protection management plans, regulatory systems and tourism programmes. ${ }^{47}$

\section{The Myth that Underwater Cultural Heritage Cannot be Listed as World Heritage}

Despite the undeniable case for placing universally outstanding UCH sites on the World Heritage List, there has been a lack of research toward this end. In 1993, Henry Cleere, World Heritage Coordinator for the International Committee of Monuments and Sites (ICOMOS) - the expert body which advises the World Heritage Committee on all cultural heritage nominations and management ${ }^{48}$ - noted in a brief article that the 'time would seem to be right' to explore adding UCH to the World Heritage List. ${ }^{49} \mathrm{He}$ added that there is nothing in the World Heritage Convention explicitly prohibiting the listing of $\mathrm{UCH}$ and that the Convention, in fact, appears to encourage it. ${ }^{50}$ Nevertheless, he felt that the principal difficulty could be the Committee's prohibition on listing 'movable heritage', under Paragraph 48 of their Operational Guidelines for the Implementation of the World Heritage Convention ("Operational Guidelines"). ${ }^{51}$ He then referred to the raisings of the Vasa in Stockholm and the Mary Rose in Portsmouth as evidence of such movability. ${ }^{52}$ Nevertheless, he did then acknowledge that the Operational Guidelines are an organic 'functional' document, which could easily be amended by the Committee. ${ }^{53}$

As negotiations on the draft UCH Convention were commencing in 1995, it was noted by experts during a Preliminary Report to the United Nations Education, Social and Cultural Organisation (UNESCO), that the World Heritage Convention would not provide sufficient protection alone for $\mathrm{UCH}^{54}$ This is, first, because additional regulation would be needed for objects obtained from UCH sites, rather than the sites themselves. ${ }^{55}$ Second, and just as correctly, this is because the vast majority of $\mathrm{UCH}$ would not qualify as carrying 'outstanding universal value' (OUV), as required to be

47 J Thorsell, World Heritage Convention: Effectiveness 1992-2002 and Lessons for Governance (Parks Canada, Gatineau, 2003) Cat. No. R62-362/2002E (available at https://www.iucn.org/sites/dev/files/import/downloads/effectiveness.pdf; accessed 22 June 2017.

${ }^{48}$ World Heritage Convention (n 1), Arts. 13(7) and 14(2); Operational Guidelines (n 12), at para. 144.

${ }^{49} \mathrm{H}$ Cleere, 'The underwater heritage and the World Heritage Convention', (1993), 17(2)

Bulletin of the Australian Institute for Maritime Archaeology 25-26, at p. 26.

${ }^{50}$ Ibid., at p. 25.

${ }^{51}$ Ibid.

52 Ibid.; R Saunders, The Raising of the Vasa; The Rebirth of a Swedish Galleon (Oldbourne, London, 1962); Mary Rose Trust, 'Raising the Mary Rose' available at http://www.maryrose.org/discover-our-collection/story-of-the-ship/raising-the-mary-rose; accessed 22 June 2017.

${ }^{53}$ Cleere (n 49), at p. 26.

${ }^{54}$ UNESCO, 'Preliminary Report on the Advisability of Preparing an International Instrument Protecting Underwater Cultural Heritage', in General Conference, Twenty-eighth session, Paris, 1995 (UNESCO, Paris, 4 October 1995) UN Doc. 28 C/39, available at http://unesdoc.unesco.org/images/0010/001026/102628e.pdf; accessed 7 September 2017, at para. 43.

${ }^{55}$ Ibid. 
inscribed on the List. ${ }^{56}$ Critically, however, this statement should never have been taken to mean that the World Heritage Convention is not open to also protecting those sites that $d o$ possess OUV. Nevertheless, in a short article on UCH in the World Heritage Newsletter the following year, we are casually reminded: '[i]t will be recalled that the underwater heritage is not covered by the World Heritage Convention.' ${ }^{57}$ Contrastingly, Strati informed us during the $\mathrm{UCH}$ Convention negotiations that there is nothing to stop the listing of $\mathrm{UCH}$ on the World Heritage List provided such sites are within the territorial sea. ${ }^{58}$ She refers, in particular, to the World Heritage Convention's Article 3, which requires that property is nominated by the territorial state in which it is located. ${ }^{59}$

In 2004, Jeffery questioned the possibility of listing the remarkable Truk Lagoon as a World Heritage Site. ${ }^{60}$ For him, however, it was the lack of effective management and regulatory protection for the lagoon, as well as its overlapping claims of ownership, which could present the greatest difficulty. ${ }^{61}$ Unfortunately, however, he does not explore any of these legal issues to which he refers. In 2007, Spennemann highlighted the growing challenge of 'extreme cultural tourism' at sites like Antarctica, the Moon and the Titanic. ${ }^{62}$ He reminds us of the difficulty with the World Heritage Convention requiring nominations from a territorial state, adding further that Articles 4 and 11(1) also require the territorial state to bear the primary responsibility for protecting and managing listed properties, as well as for listing and ultimately accepting sites onto the List. ${ }^{63}$ Interestingly, however, he remarks that multilateral cooperation could overcome this implicit need for territoriality in the Convention, saying that the Antarctic Treaty ${ }^{64}$ and the UCH Convention 'demonstrate that binding multilateral agreements on the protection of cultural and natural heritage can be reached in areas where territoriality is absent. ${ }^{, 65}$

In 2014, Khakzad also briefly recounted that the two primary issues with listing $\mathrm{UCH}$ are the regulatory complexity with sites beyond territorial

\footnotetext{
${ }^{56}$ World Heritage Convention (n 1), Arts. 1, 2 and 11(2); Operational Guidelines (n 12), at para. 77.

57 UNESCO, World Heritage Newsletter, No. 13 (UNESCO, January 1997), according to B Jeffery, 'Historic Shipwrecks Legislation' in M Staniforth and M Nash (eds), Maritime Archaeology: Australian Approaches (Springer, New York, 2006) 123-133, at p. 131.

58 A Strati, Draft Convention on the Protection of Underwater Cultural Heritage: A Commentary Prepared for UNESCO (UNESCO, Paris, 1999) Doc. CLT-99/WS/8, available at http://unesdoc.unesco.org/images/0011/001159/115994eo.pdf; accessed 7 September 2017, at p. 87; Strati had in fact made similar points in 1991 (see A Strati, 'Deep Seabed Cultural Property and the Common Heritage of Mankind', (1991), 40(4) International \& Comparative Law Quarterly 859-894, at )

${ }^{59}$ Ibid.; World Heritage Convention (n 1), Art. 3: 'It is for each State Party to this Convention to identify and delineate the different properties situated on its territory'.

60 Jeffery (n 42).

${ }^{61}$ Ibid., at p. 118.

${ }^{62}$ DHR Spennemann, 'Extreme Cultural Tourism: From Antarctica to the Moon', (2007), 34(4) Annals of Tourism Research 898-918.

${ }^{63}$ Ibid., at p. 908; World Heritage Convention (n 1), Arts. 4 and 11(3).

${ }^{64} 1959$ Antarctic Treaty (Washington, 1 December 1959; in force 23 June 1961) 402 UNTS 71.

${ }^{65}$ Spennemann (n 62), at p. 908 .
} 
waters and the issue of UCH's supposed movability. ${ }^{66}$ Meanwhile, UCH experts, James Delgado and Ole Varmer casually noted in 2015 that 'it may be worth exploring' how the World Heritage Convention could help protect $\mathrm{UCH}^{67}$ In 2015, Hershey finally addressed the legal challenges with listing the Titanic on the World Heritage List, including some of the issues of jurisdiction and ownership, if only briefly. ${ }^{68} \mathrm{He}$ points out, quite correctly, that there appears to be some flexibility in the World Heritage Convention in terms of listing sites beyond territorial waters. ${ }^{69}$ For example, Article 11(3) says that properties can be nominated from within areas where more than one state claims jurisdiction. ${ }^{70}$ He further stresses, as with Cleere, that nowhere does the World Heritage Convention explicitly prohibit such listings. ${ }^{71} \mathrm{He}$ then proposes ways in which Articles 3, 4 and 11 - requiring the territorial state's involvement - could be dealt with from a theoretical (rather than practical) standpoint. For example, suggesting that as such property arguably forms a res communis, rather than a res nullius, perhaps every state can nominate such sites, rather than no state. ${ }^{72}$ This argument is enforced, he suggests, by the fact that many UCH properties have no identifiable owners and thus no one to object to such nominations. ${ }^{73}$ Alternatively, he suggests, nominations could come from those with an identifiable legal interest in such sites. ${ }^{74}$ However, his assessment of who would carry such a 'legal interest' over the Titanic is only fleeting and bears little connection with any of the principal legal rules. ${ }^{75}$

In conclusion, despite Henry Cleere's appeal back in 1993, the nomination or listing of any outstanding $\mathrm{UCH}$ as world heritage has yet to occur. It is almost as if the conclusion of the UCH Convention led to the very

\footnotetext{
${ }^{66}$ S Khakzad, 'Underwater Cultural Heritage Sites on the Way to World Heritage: To Ratify the 2001 Convention or not to Ratify?', (2014), 2(1) Journal of Anthropology and Archaeology 1-16.

${ }^{67}$ J Delgado \& O Varmer, 'The Public Importance of World War I Shipwrecks: Why a State Should Care and the Challenges of Protection' in U Guérin, A Rey da Silva and L Simonds (eds), Underwater Cultural Heritage from World War I, Proceedings from the Scientific Conference on the Occasion of the Centenary of World War I, Bruges, Belgium, 26 \& 27 June 2014 (UNESCO, Paris, 2015) 105-116, at p. 111.

${ }^{68}$ P Hershey, 'RMS Titanic as National and World Heritage: Protecting the Wreck Site of the Titanic Pursuant to the National Historic Preservation Act and the World Heritage Convention', (2015), 16(3) Florida Coastal Law Review 279-301.

${ }^{69} \mathrm{Ibid}$., at p. 286.

${ }^{70}$ Ibid., at pp. 284-285.

${ }^{71}$ Ibid., at p. 283.

${ }^{72}$ Ibid., 'because the high seas are common property shared jointly by all international states, any state with an identifiable interest in the Titanic wreck site should be allowed to nominate the site to the World Heritage List, if not any (or every) international state.'

${ }^{73}$ Ibid., at p. 294.

${ }^{74}$ Ibid.

75 Ibid., at p. 293, suggests that Canada, US and UK, as well as US-based company RMS Titanic Inc., have a potential legal interest. This is on the basis of the wreck's location, the fact that it was British-flagged and because the US has issued salvage awards over the wreck. Other efforts in the past to determine the states 'linked' to the Titanic have also been remarkably inconsistent, compare, e.g., PV Niemeyer 'Applying Jus Gentium to the Salvage of the R.M.S. Titanic in International Waters - The Nicholas J. Healy Lecture', (2005), 36(4) Journal of Maritime Law \& Commerce 331-446, at p. 445; and MJ Aznar \& O Varmer, 'The Titanic as Underwater Cultural Heritage: Challenges to its Legal International Protection', (2013), 44(1) Ocean Development and International Law 96-112, at p. 102; Also see infra (nn 145-163 and 188-234).
} 
idea being dropped. Only recently is commentary on the issue re-emerging, but there still remains a lack of any proper analysis of the practical and legal issues associated with getting UCH listed. The remainder of this paper finally provides that analysis.

\section{RMS Titanic and RMS Lusitania as Potential Candidates for the World Heritage List}

With an estimated three million wrecks worldwide, along with countless other submerged vehicles, structures, objects and landscapes, ${ }^{76}$ it is not the purpose of this paper to prejudge those suited for world heritage listing. Nevertheless, among all these options, the wreck sites of the Titanic and Lusitania could be two of the strongest candidates. They also happen to carry characteristics which make them especially suitable case studies.

\section{RMS Titanic}

The RMS Titanic must be the world's first choice as a UCH site of outstanding universal value. Largely regarded as the most famous shipwreck of all time, and perhaps the most famous disaster, the story of the Titanic's fateful voyage in April 1912 is continuously recounted in literature, television, pictures and film. James Cameron's 1997 movie Titanic is the second-highest grossing film of all time ${ }^{77}$ and soon two full-size reconstructions of the ship will be unveiled in both Australia and China. ${ }^{78}$ In addition to the world-leading $£ 100 \mathrm{~m}$ Titanic museum launched in Belfast in $2012,{ }^{79}$ there are also dedicated museums and permanent exhibits in the United States, United Kingdom, Ireland and Canada. ${ }^{80}$ The wreck herself has become almost as famous as the story. The fascinating images of Robert Ballard and Jean-Louis Michel's famous discovery of the wreck in $1985,{ }^{81}$ along with subsequent visits to the

\footnotetext{
${ }^{76}$ UNESCO, 'Wrecks' available at http://www.unesco.org/new/en/culture/themes/underwatercultural-heritage/ underwater-cultural-heritage/wrecks; accessed 23 June 2017.

77 Box Office Mojo, 'All Time Box Office' available at http://www.boxofficemojo.com/alltime/world; accessed 23 June 2017.

78 A Rourke, 'Titanic II: Australian billionaire announces plan to rebuild liner' available at https://www.theguardian.com/world/2012/apr/30/titanic-ii-australian-rebuild-liner; accessed 23 June 2017; BBC News, 'Chinese theme park Titanic replica upsets families' available at http://www.bbc.co.uk/news/uk-england-hampshire-39544568; accessed 23 June 2017.

79 'Titanic Belfast' available at http://titanicbelfast.com; accessed 23 June 2017.

80 'Titanic - The Artifact Exhibition' available at http://www.premierexhibitions.com/exhibitions/3/3/titanic-artifact-exhibition; accessed 23 June 2017; 'Titanic Branson' (USA) available at http://www.titanicbranson.com; accessed 23 June 2017; SeaCity Museum, 'Southampton's Titanic Story' available at http://seacitymuseum.co.uk/?page_id=229; accessed 23 June 2017; 'Titanic Experience Cobh' available at: http://www.titanicexperiencecobh.ie; accessed 23 June 2017; Maritime Museum of the Atlantic, 'Titanic: The Unsinkable Ship and Halifax' available at https://maritimemuseum.novascotia.ca/what-see-do/titanic-unsinkable-ship-and-halifax; accessed 23 June 2017.

81 National Geographic, 'Photo Gallery: Discovering the Titanic' available at http://ocean.nationalgeographic.com/ocean/photos/discovering-titanic/\#/mir-submersiblekristof_18399_600x450.jpg; accessed 23 June 2017; WJ Broad, 'Wreckage of Titanic Reported Discovered 12,000 Feet Down' available at http://www.nytimes.com/ 1985/09/03/science/wreckage-of-titanic-reported-discovered-12000-feet-down.html? page wanted=all; accessed 23 June 2017.
} 
site from countless tourists and scientists, continue to captivate audiences. Pictures of the wreck, covered in orange, red and brown "rusticles", ${ }^{82}$ compressed $2 \frac{1}{2}$ miles down in the frigid, pitch-black depths of the Atlantic, are immediately recognisable around the world. ${ }^{83}$

Despite this global appreciation, there are many specific threats facing the wreck site which require urgent international attention. Both the bow and stern structures are rapidly deteriorating, and are at risk of total collapse, as a result of previously unknown iron-consuming bacteria. ${ }^{84}$ This unfamiliar bacterium, Halomonas titanicae, has itself become an object of devoted scientific analysis. ${ }^{85}$ So vigorous and virulent is its rate of consumption, that many see saving the Titanic from totally disappearing within a few decades as a hopeless cause. ${ }^{86}$ However, not all. Ballard is convinced that his plan to paint the ship's hull with antifouling paint is both realistic and could add many decades or centuries to the ship's life while better preservation technology is developed. ${ }^{87}$ In fact, Ballard and the US National Oceanic and Atmospheric Administration (NOAA) stress that their main concern is the ever-increasing unregulated human activity at the site, including looting, interference, pollution and damage caused by submersibles making contact with the structure. ${ }^{88}$

Activity at the site has continued growing, as deep-sea technology becomes more available and affordable. Russian companies, in cooperation with US investors and experts, provide tourism trips to the site, causing much of this human interference and pollution. ${ }^{89}$ China, France and Japan also

\footnotetext{
82 The term "rusticle" was coined by Robert Ballard himself (Oxford Online Dictionaries, 'rusticle' available at https://en.oxforddictionaries.com/definition/ rusticle; accessed 23 June 2017).

${ }^{83}$ The economic significance of photographs of the wreck has even led to embittered litigation in the United States over the possible rights of salvors to prevent the development and distribution of such images (R.M.S Titanic Inc. v. Haver 171 F.3d 943 ( $4^{\text {th }}$ Cir. 1999)).

${ }^{84}$ E.g., J Fox-Skelly, 'The wreck of the Titanic is being eaten and may soon vanish' available at http://www.bbc.com/earth/story/20170310-the-wreck-of-the-titanic-is-being-eaten-andmay-soon-vanish; accessed 23 June 2017.

85 C Sánchez-Porro, B Kaur, H Mann and A Ventosa, 'Halomonas titanicae sp. nov., a halophilic bacterium isolated from the RMS Titanic', (2010), 60(12) International Journal of Systematic and Evolutionary Microbiology 2768-2774.

${ }^{86}$ Ibid.; Fox-Skelly (n 84); S Augustine, “Extremophile Bacteria' Will Eat Away Wreck of the Titanic by 2030' available at https://www.laboratoryequipment.com/news/2016/09/extremophile-bacteria-will-eat-awaywreck-titanic-2030; accessed 23 June 2017.

87 RD Ballard and MJ Durbin, 'Long-term Preservation and Telepresence Visitation of Cultural Sites beneath the Sea' in RD Ballard (ed), Archaeological Oceanography (Princeton University Press, New Jersey, 2008) 249-262, at p. 258; JJ Lee, 'New Plans Could Protect the Titanic, 30 Years After It Was Found' available at http://news.nationalgeographic.com/2015/08/150901-titanic-shipwreck-discovery-30anniversary-archaeology-oceans-science; accessed 23 June 2017.

88 Ballard and Durbin (ibid.), at p. 260; Following a letter to the International Maritime Organisation from the US Coast Guard and signed by NOAA and the US National Park Service, the IMO issued a non-binding circular advising vessels to refrain from polluting in a 10-square mile zone above the wreck - (International Maritime Organization, Pollution Prevention Measures in the Area Surrounding the Wreckage of the RMS Titanic Communication Received from the United States Coast Guard (London, 31 January 2012) MEPC.1/Circ.779, available at https://nmssanctuaries.blob.core.windows.net/sanctuaries$\mathrm{prod} / \mathrm{media} /$ archive/maritime/titanic/pdfs/coastguard.pdf; accessed 7 September 2017).

${ }^{89}$ Ballard and Durbin (ibid.) at p. 260.
} 
possess the technology to reach these depths. ${ }^{90}$ Furthermore, US-based company RMS Titanic, Inc. (RMST) continues to assert its salvor-inpossession status over the site under United States law (see infra) and to retrieve artefacts from the debris field. ${ }^{91}$ Recent estimates suggest that over 6,000 artefacts have already been looted from this "legitimate" activity; with many more being taken from unregulated activities. ${ }^{92}$ An international plan of action, replete with commitments between states and stakeholders to cooperate in the site's long-term protection, must therefore be on our immediate agenda.

\section{RMS Lusitania}

One could conceivably make a case for the RMS Lusitania being the secondmost famous shipwreck of all time. In several ways, there are similarities in their stories: both were world-leading steam-powered transatlantic passenger liners owned by Liverpool-based lines, sinking just three years apart, and representing a similar loss of civilian life. ${ }^{93}$ However, the Lusitania's significance is not just the similarly tragic nature of the story, but from the event's importance within a historical context. Sunk by a single torpedo from German submarine $U-20$ while she made her way through Irish waters towards Liverpool from New York in 1915, the deaths of 128 American civilians among the 1,198 lost is widely regarded as a key moment triggering American action in World War I. ${ }^{94}$ Her distinction is bigger yet still by two well-known controversies surrounding the disaster: first, that she was carrying a secret cargo of munitions for the war in Europe, which Germany later argued made her a valid wartime target; ${ }^{95}$ and, second, the plausible theory that the British War Cabinet intentionally taxied her, without a naval escort, through waters where $U-20$ was known to be on the prowl, intending to ultimately attract American sympathies in the war. ${ }^{96}$ From a historical perspective, therefore, the Lusitania is as important to WWI as Pearl Harbor was to WWII. The story still attracts global fame and attention, along with hundreds of thousands of

\footnotetext{
${ }^{90}$ Current deep-sea submersible technology includes: China's Jiaolong (F Liu, W Cui and X Li, 'China's first deep manned submersible, JIAOLONG', (2010) 53(10) Science China Earth Sciences 1407-1410); Japan's Shinkai 6500 (Japan Agency for Marine-Earth Science and Technology, 'Deep Submergence Research Vessel: Shinkai 6500' available at http://www.jamstec.go.jp/e/about/equipment/ships/shinkai6500.html; accessed 23 June 2017); and France's Archimède (W Sullivan, '3 Craft to Dive Deep in Mid-Atlantic Valley', http://www.nytimes.com/1974/05/21/archives/3-craft-to-dive-deep-in-midatlantic-valley-60plunges-to-study-the.html?nytmobile=0; accessed 23 June 2017).

91 T McGlone, 'Norfolk judge grants salvage award for Titanic artifacts' available at https://pilotonline.com/news/local/crime/norfolk-judge-grants-salvage-award-for-titanicartifacts/article_e235da24-d922-5b43-9e59-c72e90494253.html; accessed 23 June 2017.

92 Ibid.; Department for Transport, Consultation on the Implementation of the Agreement for the protection of the wreck of the RMS Titanic (London, 7 April 2003) Annex A (available at http://www.jnapc.org.uk/Consultation\%

20on\%20Protection\%20of\%20RMS\%20Titanic\%20by\%20DoT\%202003.pdf; accessed 23 June 2017), at para. 4.2.

93 See generally, E Larson, Dead Wake: The Last Crossing of the Lusitania (Black Swan, London, 2015). The Titanic was operated by the White Star Line and the Lusitania by the Cunard Line which, in the early twentieth century, were both registered in Liverpool.

94 History.com, 'Lusitania' available at http://www.history.com/topics/world-war-i/lusitania; accessed 23 June 2017.

${ }^{95}$ E.g., M Martin, RMS Lusitania: It Wasn't \& It Didn't (History Press Limited, Stroud, 2014).

${ }^{96}$ E.g., D Preston, Wilful Murder: The Sinking of the Lusitania (Corgi, London, 2003).
} 
visitors to permanent exhibits about the ship and wreck in Liverpool, Kinsale and Cobh. ${ }^{97}$

Located only 11/2 nautical miles off the Head of Kinsale in Ireland, the site is much closer to land and in much shallower water (around 93 metres compared with the Titanic's 3,800 metres). ${ }^{98}$ The threats facing it are therefore also markedly different. First, the wreck has regularly been snagged and dragged by fishing equipment, leaving her covered with fishing nets, ropes and tackle. ${ }^{99}$ It also faces physical pressures from tidal energy and storms, which have occasionally accelerated damage. ${ }^{100}$ Being in shallower water and closer to land, it has also been subject to various salvage and looting activities. ${ }^{101}$ It is also known to contain unexploded depth charges. ${ }^{102}$ There is therefore a strong case to properly invest in the site's protection and conservation, in order that future generations can conduct proper archaeological research or perhaps admire the site close up.

\section{The Legal and Practical Challenges of Placing Underwater Cultural Heritage on the World Heritage List}

\section{Underwater Cultural Heritage as Possessing 'Outstanding Universal Value'}

To become a World Heritage Site, one must invest considerable energy and resources in demonstrating to the World Heritage Committee ${ }^{103}$ that the property possesses cultural or natural heritage of 'outstanding universal value' ${ }^{104}$ It must be said, at the outset, that nowhere has it been suggested that UCH could not carry such OUV. A dedicated international treaty - in the form of the UCH Convention - which acknowledges 'the importance of

97 Merseyside Maritime Museum, 'Lusitania Collection' available at http://www.liverpoolmuseums.org.uk/maritime/collections/lusitania; accessed 23 June 2017; Wild Atlantic Way, 'Lusitania Museum and Old Head Signal Tower' available at http://www.wildatlanticway.com/directory/cork/eat-drink-nightlife/cafes-restaurants/

details/lusitania-museum-and-old-head-signal-tower; accessed 23 June 2017; Cobh Heritage Centre, 'Lusitania Exhibition' available at http://www.cobhheritage.com/lusitania; accessed 23 June 2017.

98 Wrecksite.eu, 'RMS Lusitania' available at http://www.wrecksite.eu/wreck.aspx?10126; accessed 23 June 2017; Wrecksite.eu, 'RMS Titanic' available at http://www.wrecksite.eu/wreck.aspx?10124; accessed 23 June 2017.

99 T Carey, 'The Lusitania's last resting place' available at http://www.independent.ie/news/special-features/lusitania-100/the-lusitanias-last-restingplace-31168537.html; accessed 23 June 2017.

${ }^{100}$ RD Ballard, 'Exploring the Lusitania' (excerpted from RD Ballard and R Archbold, Lost Liners (Hyperion, New York, 1997)) available at http://www.pbs.org/lostliners/lusitania.html; accessed 23 June 2017.

$101 \quad$ Shipwreck 'RMS Lusitania' available at http://www.shipwreckworld.com/maps/rms-lusitania; accessed 23 June 2017.

102 Lusitania Online, 'Lusitania's Last Resting Place' available at http://www.lusitania.net/lastrestingplace.htm; accessed 23 June 2017.

103 As well as its technical advisors, particularly ICOMOS for the management of cultural heritage, and the International Union for the Conservation of Nature (IUCN) for the management of natural heritage (World Heritage Convention (n 1), Arts. 13(7) and 14(2)); Obura and Bertzky (n 15), at p. 129.

${ }^{104}$ World Heritage Convention (n 1), Arts. 1, 2 and 11(2); Operational Guidelines (n 12), at para. 77. 
underwater cultural heritage as an integral part of the cultural heritage of humanity', ${ }^{105}$ and which calls on states to preserve UCH 'for the benefit of humanity', ${ }^{106}$ would make it hard to argue that such a 'common concern of humankind' could not carry potential OUV. ${ }^{107}$ Under Article 2 of the World Heritage Convention, UCH would also appear to qualify as 'cultural heritage' in the form of a 'site'. ${ }^{108}$ Prima facie, therefore, the Titanic and Lusitania could qualify.

However, the Operational Guidelines then provide the detail on how the Committee would assess OUV in each case. First, Paragraph 49 defines OUV as 'cultural and/or natural significance which is so exceptional as to transcend national boundaries and to be of common importance for present and future generations of all humanity.' It has already been shown that the Titanic and Lusitania appear to carry these values. The universality and intergenerationality of interest in the Titanic - with reconstructions in Australia and China, dedicated museums in the United States, United Kingdom, Canada and Ireland, and with high-grossing sales of the Hollywood movie around the world - is patently clear. ${ }^{109}$ The Lusitania wreck is also likely of exceptional and of common enough importance to transcend national borders and, in particular, to go beyond merely national or regional heritage. ${ }^{110}$

A potential difficulty could arise, however, in the remainder of Paragraph 49, which suggests that 'the permanent protection of this heritage is of the highest importance to the international community as a whole'. Some might question whether the 'permanent' protection of the Titanic or Lusitania is of the highest importance. For example, arguing that investing to reverse their natural degradation would be a hopeless and supererogatory fight against nature. ${ }^{11}$ However, the very point of listing World Heritage is to reverse the imminent dangers or risks to sites, both natural and anthropogenic. ${ }^{112}$ The

${ }^{105}$ UCH Convention (n 1), Preamble.

106 UCH Convention (n 1), Art. 2(3).

107 EB Weiss, 'Nature and Law: The Global Commons and the Common Concern of Humankind' in PS Dasgupta, V Ramanathan and MS Sorondo (eds), Sustainable Humanity, Sustainable Nature, Our Responsibility - The Proceedings of the Joint Workshop on 2-6 May 2014, Pontificiae Academiae Scientiarvm Extra Series 41 (The Pontifical Academy of Sciences, Vatican City, 2015), at p. 12; Note also similar wording in the Preamble to the World Heritage Convention (n 1), which calls on states parties to preserve outstanding 'heritage of mankind as a whole', as well as the Operational Guidelines (n 12) which declare, at para. 4, that 'cultural and natural heritage is among the priceless and irreplaceable assets, not only of each nation, but of humanity as a whole' and, at para. 7, that the 'Convention aims at the identification, protection, conservation, presentation and transmission to future generations of cultural and natural heritage'.

${ }^{108}$ World Heritage Convention (n 1), Art. 2 states that cultural heritage could be in the form of a 'site' which contains 'works of man . . . and areas including archaeological sites which are of outstanding universal value from the historical, aesthetic, ethnological or anthropological point of view.' UCH could also potentially qualify as a 'monument' under the same definition, by possessing 'architectural works [or] elements or structures of an archaeological nature ... . which are of outstanding universal value from the point of view of history, art and science'.

${ }^{109}$ E.g., Hershey (n 68), at p. 281, says the Titanic 'is an archeological [sic] site of extreme universal, historical, and cultural importance'.

${ }^{110}$ Operational Guidelines (n 12), at para. 52.

${ }^{111}$ See (nn 84-86).

112 The opening statement in the World Heritage Convention (n 1) Preamble, declares that outstanding world heritage 'is increasingly threatened with destruction not only by the traditional causes of decay, but also by changing social and economic conditions which 
same argument could be used for the majority of terrestrial World Heritage archaeological sites and buildings which require unceasing, and potentially much costlier, conservation against natural degradation. ${ }^{113}$

Most importantly, when assessing OUV under the Operational Guidelines, one must turn to Paragraph 77, which lists ten different criteria which suggest OUV, and Paragraph 78, which requires that the property must also meet the conditions of integrity, authenticity and have an adequate protection and management system. ${ }^{114}$ \{Emphasis supplied.\} The first six criteria listed in Paragraph 77 relate to 'cultural' heritage and the last four criteria to 'natural' heritage. It is easily conceivable that UCH could satisfy any of the ten listed criteria, depending on each site's cultural, historical and natural context. ${ }^{115}$ For the Titanic and Lusitania, they could both be said to satisfy criterion (vi), as being 'directly or tangibly associated with events . . . of outstanding universal significance.' However, problematically, the Committee 'considers that this criterion should preferably be used in conjunction with other criteria'. ${ }^{116}$

For the Titanic, one could possibly argue that dramatic changes in international maritime safety regulations after the disaster help satisfy criterion (iv), as an 'example of a[n] architectural or technological ensemble . . . which illustrates a significant stage in human history'. ${ }^{117}$ More confidently, however, one could argue that its unusual bacteriological and biochemical ecosystem represents a 'superlative natural phenomenon' under the 'natural' criterion (vii), thus making it a 'mixed' heritage site. ${ }^{118}$ It might be tempting to also argue that the ship's architecture represents 'a masterpiece of creative human genius' under criterion (i). However, it is worth noting that this is usually awarded to either unique or to the very best examples of such creative outputs. ${ }^{119}$ One could contend, therefore, that the better condition of the wreck

aggravate the situation'. Art. 11(4) lists specific threats which could suggest heritage being in danger, which are mostly natural threats such as 'the threat of disappearance caused by accelerated deterioration', 'major alterations due to unknown causes', 'calamities and cataclysms', 'serious fires, earthquakes, landslides', 'volcanic eruptions', 'changes in water level, floods and tidal waves'. Most tellingly, it also regards 'abandonment for any reason whatsoever' as a serious threat.

${ }^{113}$ E.g., ICOMOS, International Charter for the Conservation and Restoration of Monuments and Sites (Venice, 1964) available at https://www.icomos.org/charters/venice_e.pdf; accessed 23 June 2017, Art. 4, 'It is essential to the conservation of monuments that they be maintained on a permanent basis'; ICOMOS, Charter for the Protection and Management of the Archaeological Heritage (Lausanne, 1990) available at http://www.icomos.org/charters/arch_e.pdf; accessed 23 June 2017, Art 6., 'The overall objective of archaeological heritage management should be the preservation of monuments and sites in situ, including proper long-term conservation and curation of all related records and collections etc. [. . .] This principle stresses the need for proper maintenance'; See generally, S Sullivan and R Mackay (eds), Archaeological Sites: Conservation and Management (Getty Publications, Los Angeles, 2013).

114 The conditions within para. 78 of the Operational Guidelines (n 12) are then elaborated in paras. 79-119.

115 E.g., The SS President Coolidge is the only shipwreck site to be added to World Heritage Tentative List (UNESCO World Heritage Tentative List, 'SS President Coolidge', available at http://whc.unesco.org/en/tentativelists/1972/; accessed 7 September 2017).

116 Operational Guidelines (n 12), at para. 77(vi).

${ }^{117}$ Ibid., at para. 77(iv).

118 Sánchez-Porro et al. (n 85); Hershey (n 68), at p. 282.

119 D Marshall (ed), Preparing World Heritage Nominations - Resource Manual (2 $2^{\text {nd }}$ ed., UNESCO, Paris, 2011), at p. 34. 
of the HMHS Britannic, the Titanic's sister ship torpedoed during WWII, might provide the 'best' representation of the White Star Line's Olympic Class. ${ }^{120}$

For the Lusitania, however, the approach to the conjunctive criteria requirement must be different. Its strongest argument is to satisfy criterion (iv) as an outstanding example of a technological ensemble representing a significant stage in human history. According to Marshall, the 'essence of this criterion is that it must in some way demonstrate that it is associated with a defining moment . . . in human history. [ . . .] The historical moment needs to be deemed of outstanding importance, as do its repercussions. The stages may relate to political or economic history . . . which had far-reaching consequences.' $^{121}$ The Lusitania therefore appears to satisfy these grounds. It is also worth bearing in mind that the Committee's aim to use criterion (vi) in conjunction with other criteria is only advisory. For example, Auschwitz Birkenau Concentration Camp and the Hiroshima Peace Memorial - two important and defining moments in wartime history - were added to the World Heritage List on the basis of criterion (vi) alone. ${ }^{122}$

The second two requirements of Paragraph 78, of integrity and a protection management system, are explored in the final two sections. In terms of the final requirement of authenticity, there is no indication that the Titanic or Lusitania would have any difficulties here. Its central tenet is that cultural sites remain true and accurate reflections of their original selves, and that the values and significance ascribed to them can be reasonably verified. ${ }^{123}$ Although Paragraph 86 holds that 'the reconstruction of archaeological remains . . . is justifiable only in exceptional circumstances', it is not likely that Ballard's plan to coat the hull in a protective paint, using a neutral colour that maintains its current appearance, ${ }^{124}$ would be seen as a "reconstruction" of the Titanic wreck.

There might also be a question on how Paragraph 52 affects the Lusitania. It implies that the Committee will list only the best examples of certain values, not all examples. Therefore, if one were to superficially view the Titanic and Lusitania as two British-built transatlantic passenger liners,

120 Wrecksite.eu, 'HMHS Britannic', available at http://wrecksite.eu/wreck.aspx?135787; accessed 23 June 2017; M Chirnside, The Olympic Class Ships: Olympic, $\underline{\text { Titanic, Britannic }}$ ( $2^{\text {nd }}$ ed., History Press, Stroud, 2011).

${ }^{121}$ Marshall (n 118), at p. 37.

122 UNESCO World Heritage List, 'Auschwitz Birkenau' available at http://whc.unesco.org/en/list/31; accessed 23 June 2017; UNESCO World Heritage List, 'Hiroshima Peace Memorial' available at http://whc.unesco.org/en/list/775; accessed 23 June 2017); c.f., Note, however, that the Committee entered Auschwitz 'as a unique site' wishing 'to restrict the inscription of other sites of a similar nature' (World Heritage Committee, 'Report of the Rapporteur on the Third Session of the World Heritage Committee' in World Heritage Committee, Convention Concerning the Protection of World Cultural and Natural Heritage, Third Session, Cairo \& Luxor, 22-26 October 1979 (UNESCO, Paris, 30 November 1979) CC-79/CONF.003/13, available at http://whc.unesco.org/archive/1979/cc-79-conf00313e.pdf; accessed 7 September 2017, at para. 46).

123 Operational Guidelines (n 12), at paras. 79-86. Leaving aside the implausible conspiracy theory that the Titanic was in fact the RMS Olympic, e.g., S Hall and B Beveridge, Olympic \& Titanic: The Truth Behind the Conspiracy (Infinity Publishing, Conshohocken, 2004).

124 B Handwerk, 'Paint the Titanic, Wreck's Discoverer Says' (available at http://news.nationalgeographic.com/news/2012/04/120412-titanic-100-anniversary-paintballard-science; accessed 23 June 2017). 
built and lost around the same time, and both involving a significant loss of civilian life, then you might suggest that only one example would suffice. However, as noted, the global value and significance attached to the Lusitania - based on its pivotal role within WWI - is wholly distinguishable from the Titanic's. ${ }^{125}$ A related issue is the Committee's Global Strategy to ensure a 'representative, balanced and credible' list as noted in the first section. In particular, there is the understandable concern that poorer socioeconomic regions remain under-represented on the List. ${ }^{126}$ However, the global strategy has three elements: so, although it may be 'unbalanced' to put just two Western sites on the List; it is both a 'representative' and 'credible' illustration of the world's outstanding UCH. Furthermore, there is nothing to prevent future listings from other regions in the world. ${ }^{127}$

Finally, some may question whether the final resting place of so many people, in such tragic circumstances, should even be seen as 'heritage', rather than left undisturbed as protected gravesites. This is an ethical question beyond the nature of this paper. ${ }^{128}$ However, it is predominantly accepted that sites which once contained, or which even still contain, human remains, can be treated appropriately and most respectfully within carefully designed touristic or archaeological projects. ${ }^{129}$ There are already many such archaeological sites listed on the World Heritage List, such as burial sites ${ }^{130}$ and crypts, ${ }^{131}$ along with the aforenoted Hiroshima Peace Memorial and Auschwitz Birkenau Extermination Camp. ${ }^{132}$ There is also a persuasive argument that intimately

\footnotetext{
${ }^{125}$ See (nn 93-97).

1261994 Global Strategy (n 12); S Labadi, 'A review of the Global Strategy for a balanced, representative and credible World Heritage List 1994-2004', (2005), 7(2) Conservation and Management of Archaeological Sites 89-102.

127 E.g., The UNESCO UCH website notes a number of famous shipwrecks elsewhere, including the sunken fleet of Kublai Khan, of the Spanish Armada, the Greek Antikythera wreck, and the ships of Christopher Columbus (UNESCO, 'Wrecks' available at http://www.unesco.org/new/en/culture/themes/underwater-cultural-heritage/ underwatercultural-heritage/wrecks; accessed 23 June 2017).

${ }^{128}$ E.g., E Perez-Alvaro, 'Human remains on underwater cultural heritage: Ethics, values and law', in H Van Tilburg, S Tripati, V Walker, V Vadillo, B Fahy and J Kimura (eds), Proceedings of the $2^{\text {nd }}$ Asia-Pacific Regional Conference on Underwater Cultural Heritage, Vol. 1 (2014) 39-48, available at http://www.themua.org/collections/collections/show/15; accessed 7 September 2017; Forrest (n 33), at p. 338; UNESCO Manual for Activities Directed at UCH (n 43), at pp. 45-47.

${ }^{129}$ R Sharpley and PR Stone, The Darker Side of Travel: The Theory and Practice of Dark Tourism (Channel View Publications, Bristol, 2009).

130 E.g., UNESCO World Heritage List, 'Bronze Age Burial Site of Sammallahdenmäki' available at http://whc.unesco.org/en/list/579; accessed 23 June 2017; UNESCO World Heritage List, 'Etruscan Necropolises of Cerveteri and Tarquinia' available at http://whc.unesco.org/en/list/1158; accessed 23 June 2017); UNESCO World Heritage List, 'Skogskyrkogården' available at http://whc.unesco.org/en/list/558; accessed 23 June 2017.

131 E.g., UNESCO World Heritage List, 'Tomb of Askia' available at http://whc.unesco.org/en/list/1139; accessed 23 June 2017; UNESCO World Heritage List, 'Archaeological Sites of Bat, Al-Khutm and Al-Ayn' available at http://whc.unesco.org/en/list/434; accessed 23 June 2017.

${ }^{132}$ See (n 121); However, note that despite numerous efforts to increase their representation on the List, there remains an unfortunate lack of sites being representative of wars or major battles in human history (Jeffery (n 42), at p. 115). However, many can be found pending on the 'Tentative List' (e.g., Battlefield of Waterloo; Dardanelles and Gallipoli Battles Zones in the First World War; Shaubak Castle; Kokoda Track and Owen Stanley Ranges; Archaeological site of Nikopolis; The Walk of Peace from the Alps to the Adriatic).
} 
studying and cherishing such sites pays more, not less, respect and remembrance to those who died in such tragic circumstances.

\section{Underwater Cultural Heritage as 'Immovable' Heritage}

For too long it has been presumed impossible to place UCH on the World Heritage List because of the Committee's decision that only 'immovable' property be considered. ${ }^{133}$ This argument must at last be forcefully rebutted. At the outset, one must stress the sheer impossibility of raising a gigantic, fragile and incredibly heavy structure like the Titanic, along with the surrounding $5.2 \mathrm{~km}^{2}$ archaeological debris field. ${ }^{134}$ The lifting of the Lusitania - a 78-storey 'skyscraper' on its side, embedded in the seabed down at aircrushing depths, and in an immensely fragile and decrepit state - would also be a mind-blowing engineering feat. It would much easier to move Stonehenge by comparison. The Vasa and the Mary Rose liftings, referred to by Cleere earlier, were expensive and audacious experiments. But at 32-metre and 11-metre depths, and tonnages of 1,210 and 500, respectively - compared with the Titanic and Lusitania's 3,800-metre and 93-metre depths, and 46,000 and 31,550 tonnages, respectively - one has to be realistic. It is also worth noting the overall cost and complexity of the Vasa and Mary Rose experiments, which demanded decades of expensive conservation and restoration work needed to save them from ex situ deterioration. ${ }^{135}$

At its Twentieth Session, in 1996, the Committee provided a wonderfully informative definition of "movable property", as being "property that can be easily moved.' 136 Just as helpfully, "immovable property" is distinguished as "property that cannot be easily moved. The opposite of . . . movable property.' ${ }^{137}$ This does surprisingly provide one clue, however, in that it must be 'easily' moved. More helpfully, one can turn to associated sources. An Ambio special report on the World Heritage Convention in 1983 said that it would not cover 'movable items of value such as books, paintings, etc.' ${ }^{138}$ The UNESCO 1978 Recommendation for the Protection of Movable Cultural Property, negotiated around the same time that the 'immovable' requirement was introduced by the Committee, provides an extensive

\footnotetext{
${ }^{133}$ Operational Guidelines (n 12), at para. 48, 'Nominations of immovable heritage which are likely to become movable will not be considered'; E.g., Khakzad (n 66), pp. 6-7.

${ }^{134}$ S Rubin, 'Treasures of the Titanic', (1987), 164(12) Popular Mechanics 65-69, at p. 66.

135 C Summers, 'Should shipwrecks be left alone?' available at http://www.bbc.co.uk/news/magazine-15031084; accessed 23 June 2017; S Morris, 'Newly decked out Mary Rose reopens after $£ 5 \mathrm{~m}$ makeover' available at https://www.theguardian.com/culture/2016/jul/19/mary-rose-newly-decked-out-reopens-5mmakeover; accessed 23 June 2017; For all these reasons, the raising of ships has become an incredibly rare practice compared with in situ preservation - see MR Manders (ed), Guidelines for Protection of Submerged Wooden Cultural Heritage (WreckProtect, Amersfoort, 2011), at pp. 44-46.

136 World Heritage Committee, 'A Glossary of Terms relating to the Implementation of the World Heritage Convention' in World Heritage Committee, Convention Concerning the Protection of World Cultural and Natural Heritage, Twentieth session, Merida, Yucatan, Mexico, 2-7 December 1996 (UNESCO, Paris, 22 October 1996) WHC96/CONF.201/INF.21, available at http://whc.unesco.org/archive/1996/whc-96-conf201inf21e.pdf; accessed 7 September 2017.

${ }^{137}$ Ibid.

${ }^{138}$ Royal Swedish Academy of Sciences (n 35), at p. 144.
} 
definition of "movable property". ${ }^{139}$ All the examples listed therein are most discernibly objects, rather than large embedded structures or archaeological sites. The closest to UCH is 'products of archaeological exploration and excavations conducted on land and under water'. ${ }^{140}$ This very clearly refers to the 'products' of such sites, i.e., associated artefacts, and not the sites themselves. A UNESCO guide to the management of World Heritage Sites also distinguishes 'immovable' and 'movable' based on their ease of movement, using the example of 'buildings' and 'objects'. ${ }^{141}$ Finally, Ahmad provides further clues by comparing national legislative implementation of the Convention, where 'cultural heritage' has been defined as 'place, cultural significance and fabric', as 'material culture, geographic environments and human environments', as 'physical remains', or simply as 'place'. ${ }^{142}$

In sum, the understandable intention of the Committee was clearly to exclude cultural 'artefacts', given how easily they could transfer from place to place. It was certainly not meant to exclude large archaeological 'sites' or embedded structures requiring in situ preservation. ${ }^{143}$ To see otherwise could be hypocritical, considering that the World Heritage Listed vast Abu Simbel Temples were dismantled and rebuilt at a new site in response to human threats. ${ }^{144}$

\section{Ownership of $\mathrm{UCH}$}

Commentary on the international law of $\mathrm{UCH}$ has too often conflated the issues of ownership and jurisdiction. ${ }^{145}$ The two are very separate matters, although the latter may be used to determine or interpret the former. Jurisdiction will be dealt with in the following subsection.

\footnotetext{
${ }^{139}$ UNESCO, 'Recommendation for the protection of movable cultural property' in Records of the General Conference, Twentieth Session, Paris, 24 October to 28 November 1978 (UNESCO, Paris, 1979), available at http://unesdoc.unesco.org/images/0011/001140/1140 32E.pdf; accessed 7 September 2017, Annex 1, 11-17, Art. 1.

140 Ibid., Art. 1(i).

${ }^{141}$ SS Imon, LAN Dioko, CE Ong and M Kane (eds), Cultural Heritage Specialist Guide Training and Certification Programme for UNESCO World Heritage Sites: A Training Manual for Heritage Guides - Core Module, Unit 2, Tourism at Cultural Heritage Sites in Asia ( $4^{\text {th }}$ ed., UNESCO and Institute for Tourism Studies (IFT), Macao SAR, 2007) at p. 4, immovable means 'it cannot be removed from its place of origin, e.g., buildings' and 'movable' means 'it can easily be moved from one place to another, e.g., objects.'

${ }^{142}$ Y Ahmad, 'The Scope and Definitions of Heritage: From Tangible to Intangible', (2006), 12(3) International Journal of Heritage Studies 292-300, at p. 299, referring to national legislation in Australia, Canada, China and New Zealand respectively.

${ }^{143}$ JL Hall, 'Things, Inc.: A Case for In Situ Application', in JW Harris (ed), Maritime Law: Issues, Challenges \& Implications (Laws and Legislation) (Nova Science Publishers Inc., New York, 2007) 27-52; UNESCO Manual for Activities Directed at Underwater Cultural Heritage (n 43), at pp. 20-28 \& 181-183. There are of course interesting questions surrounding the point in time at which shipwrecks change from being 'movable' vessels, to archaeological 'sites' (e.g., The National Museums and Heritage Act, No. 6 of 2006 (Kenya), s.II, provides that after 50 years a shipwreck becomes a 'monument' and an integrated aspect of the landscape).

${ }^{144}$ UNESCO World Heritage List, 'Nubian Monuments from Abu Simbel to Philae' available at http://whc.unesco.org/en/list/88; accessed 23 June 2017; T Spencer, 'The Race to Save Abu Simbel is Won', (1966), 61(23) Life Magazine 32-39.

${ }^{145}$ An example is Hershey (n 62), at pp. 293-294, who equates 'legal interest' in the Titanic with potential claims of ownership (RMST's salvage interest), conflating it also with jurisdiction under international law (its placement on the Canadian continental shelf and the fact it was British-flagged).
} 
Ownership of the Titanic is a complicated subject. In most jurisdictions, ownership of UCH continues to subsist over time despite sinking. ${ }^{146}$ Naturally, however, different jurisdictions treat the question of abandonment differently. ${ }^{147}$ The Titanic was insured by a consortium of underwriters who, on paying out in 1912, each took part-ownership of the wreck, its fixtures and cargo. ${ }^{148}$ Yet, much of the documentation has long been lost and the insurers have been bought out, merged or dissolved. Nevertheless, where passage of title can be confidently shown by documentary evidence, some individuals existing today may, in a legal sense, own parts of the Titanic. ${ }^{149}$ One example is the Liverpool and London Steamship Protection and Indemnity Association, who in 1994 filed a claim of interest in the wreck against US-based salvors, $R M S T$, but were subsequently dismissed by the District Court. ${ }^{150}$ Most present-day claimants, however, would probably have little interest in 'cashing in' on a historic disaster site. Thus, given the difficulty of providing evidence to support any claims, the Titanic remains essentially ownerless.

The matter has been complicated by the United States East Virginian District Court's 1994 award of 'salvor-in-possession' status to RMST. ${ }^{151}$ The long, complex and controversial history of United States litigation over the salvage of the Titanic is beyond the object of this paper. ${ }^{152}$ However, in this particular case, District Judge Niemeyer controversially determined that the court could award RMST with an exclusive right, against all worldwide claimants, to "salvage" objects from the Titanic site. ${ }^{153}$ This was done through the judicial invention of 'constructive in rem' possession based on the retrieval of a few artefacts from the site. ${ }^{154}$ Niemeyer $\mathrm{J}$ justified his decision on the basis that some national court had to accept a petition, otherwise the Titanic believed, at that time at least (see infra), to be on the deep seabed and effectively a res nullius without any jurisdiction - would remain outside any applicable law or forum. ${ }^{155}$ For our purposes, it is important to note that RMST do not have an ownership interest in the Titanic, but title to a legal trust to salvage the site under United States common law. ${ }^{156}$ This trust has now

\footnotetext{
146 Dromgoole (n 3), at p. 102.

147 A Strati, The Protection of the Underwater Cultural Heritage: An Emerging Objective of the Contemporary Law of the Sea (Martinus Nijhoff, Leiden, 1995), at p. 125.

148 S Dromgoole and N Gaskell, 'Who has a Right to Historic Wrecks and Wreckage?', (1993), 2(2) International Journal of Cultural Property 217-274, at p. 238.

${ }^{149}$ C.f., Dromgoole (n 3), at p. 103.

150 JAR Nafziger, RK Paterson and AD Renteln (eds), Cultural Law: International, Comparative, and Indigenous (Cambridge University Press, Cambridge, 2014), at p. 321.

${ }^{151} R M S$ Titanic Inc v. Haver, 171 F.3d 943 (4 ${ }^{\text {th }}$ Cir. 1999).

152 See generally, Aznar and Varmer (n 75).

${ }^{153}$ RMST v. Haver (n 151), at paras. 166-167.

${ }^{154}$ Ibid., at para. 967; The concept was adapted from earlier United States cases which first introduced 'constructive in rem' possession of wreck sites (e.g., Columbus-America Discovery Group v. The Unidentified, Wrecked and Abandoned Sailing Vessel, 742 F. Supp. 1327 (E.D. Va., 1990), at paras. 1331 \& 1333-1334).

155 Niemeyer ( $\mathrm{n} \mathrm{75)}$; JAR Nafziger, (2003), 'The Evolving Role of Admiralty Courts in Litigation Related to Historic Wreck', 44(1) Harvard International Law Journal 251-270, at p. 259.

${ }^{156}$ RMS Titanic Inc v. Wrecked and Abandoned Vessel 435 F.3d 521 (4 $4^{\text {th }}$ Cir. 2006), at para. 536 , notes that 'the traditional law of salvage . . involves the creation of a trust relationship between salvor and the court on behalf of the owner' and that 'RMST has voluntarily and openly pursued its functions as a trustee for the public interest'. Para. 532 also says that
} 
been entered with a number of covenants and conditions through which, in cooperation with NOAA, the Virginian District Court continues to direct $R M S T{ }^{157}$ As a commercial enterprise, however, $R M S T$ have been forceful in ensuring their legal rights under US law are maintained and respected. For example, when the United States completed negotiations with the United Kingdom, France and Canada, on the International Titanic Agreement ${ }^{158}$ in 2000 (see infra), RMST took legal action against the US government to pressure them against signing the agreement. ${ }^{159}$

There is nothing in the World Heritage Convention preventing the listing of privately owned property, or of property with multiple owners. However, it would be anticipated that the benefits of ownership (e.g., tourism revenue) would be reinvested back into the site's protection or otherwise primarily used for public benefit. ${ }^{160}$ Most importantly, the Committee requires that States Parties nominating property to the List have adopted 'appropriate policy, legal, scientific, technical, administrative and financial measures' ${ }^{161}$ to protect the property, as well as 'adequate long-term legislative, regulatory, institutional and/or traditional protection and management to ensure their safeguarding [while demonstrating] adequate protection at the national, regional, municipal, and traditional level. ${ }^{162}$

It is patently clear that this could be a significant difficulty for the Titanic. The Committee would be particularly concerned that a private actor, asserting a legal interest over the site under US law, might undermine any international management plan. The ideal method for remedying this would be for the United States to reform its arguably outmoded laws on the commercial salvage of archaeological heritage. Although somewhat selfjustified through its tenuous reference to ancient rules of salvage, United States law could easily be regarded as one of the most unethical and antithetical to the $21^{\text {st }}$ century movement to prioritise the in situ conservation of $\mathrm{UCH}^{163}$ Such a reform would remove the private nature of $R M S T$ 's interest and transform it into government-regulated and conservation-oriented public

'[b]ecause a salvor acts on behalf of a true owner . . . it serves as a trustee of the owner's property and is therefore not permitted to use that property for its own purposes'.

157 Ibid., at paras. 536-538; RMS Titanic Inc v. The Wrecked \& Abandoned Vessel, No. 2:93cv902 (E.D. Va. 15 April 2008).

158 Bureau of Oceans and International Environmental and Scientific Affairs, Agreement Concerning the Shipwrecked Vessel RMS Titanic (Washington DC, 18 June 2004, not yet in force) available at http://www.gc.noaa.gov/documents/titanic-agreement.pdf; accessed 25 June 2017 ("International Titanic Agreement").

159 National Oceanic and Atmospheric Administration, 'R.M.S Titanic - Frequently Asked Questions' available at http://www.gc.noaa.gov/gcil_titanic-faqs.html; accessed 24 June 2017; c.f., $\mathrm{H} \quad$ Sides, 'Unseen - Titanic' available at http://www.nationalgeographic.com/magazine/2012/04/titanic-shipwreck-revealed-completemosaic-images; accessed 23 June 2017.

160 A Pederson, Managing Tourism at World Heritage Sites: A Practical Manual for World Heritage Site Managers (UNESCO, Paris, 2002), at pp. 34-35.

${ }^{161}$ Operational Guidelines (n 12), at para. 53.

162 Ibid., at para. 97.

${ }^{163}$ C Forrest, 'Historic Wreck Salvage: An International Perspective', (2009), 33(2) Tulane Maritime Law Journal 347-379; T Scovazzi, 'The Merits of the UNESCO Convention on the Protection of Underwater Cultural Heritage'

in F Lenzerini and S Borelli (eds), Cultural Heritage, Cultural Rights, Cultural Diversity: New Developments in International Law (Brill, Leiden, 2012) 267-299, at p. 269. 
trust, under the closer management of NOAA. ${ }^{164}$ The other alternative, perhaps more likely in the immediate future, would be for RMST to sell their interest or to unilaterally place it into a public trust which signs up to a largescale conservation plan for the site. Alternatively, they could sign the conservation management plan, or a Memorandum of Understanding, committing to use their private interests exclusively in a manner confirming with the plan's values and objectives.

The ownership of the Lusitania wreck is much less complex. The wreck represents an extraordinarily rare example of in situ UCH having an identifiable private owner. In 1968, Greg Bemis, along with several partners, bought the Lusitania wreck from the vessel's underwriters, Liverpool \& London War Risks Insurance Association. ${ }^{165}$ In 1982, Bemis then bought out his partners and became sole owner of the vessel and its registered cargo. ${ }^{166}$ Bemis is determined to discover the true nature and extent of the war munitions the Lusitania was carrying, by performing intrusive detective work such as breaking into the structure and salvaging objects. ${ }^{167}$ However, the wreck is also beloved of the Irish government who assume territorial jurisdiction over the site and who have designated it a restricted area under national monuments legislation. ${ }^{168}$ The result has been many years of legal wrangling between Bemis and the Irish government, with the tension between the two manifesting as an ongoing dispute. ${ }^{169}$

A similar issue therefore applies to the Lusitania. If Bemis were to continue asserting his legal interest for uses which are antithetical to the conservation aims of the World Heritage Convention, then the site would not carry sufficiently certain legal protection to be listed. However, if Bemis were to move his interest into a public trust, or to formally agree to manage the site according to the preservation values of the World Heritage Convention, then there is no obstacle to its listing. Perhaps more likely, given Bemis's clear resolve, is that his heirs might wish to work with the Irish government to list and protect it as a World Heritage Site.

\section{Jurisdiction and Applicable Legal Rules to $\mathrm{UCH}$}

The World Heritage Committee's requirement that properties nominated to the List possess sufficient regulatory and institutional protection ${ }^{170}$ also requires

\footnotetext{
164 The possibility for this has already been set up by the Virginian District Court adding covenants and conditions to RMST's salvage award which were intended to ensure that public interest in the site is respected (RMST v. Wrecked \& Abandoned Vessel (n 156)).

${ }^{165}$ E Mullally, 'Lusitania's Secret Cargo', (2009), 62(1) Archaeology 9.

166 R B Stolley, 'Lusitania: The Epic Battle Over Its Biggest Mystery' available at http://fortune.com/lusitania-gregg-bemis-legal-battle; accessed 24 June 2017.

${ }^{167}$ Ibid.

168 National Monuments Service, 'The Underwater Archaeology Unit and Ireland's Submerged Cultural Resource' available at https://www.archaeology.ie/underwaterarchaeology; accessed 24 June 2017.

${ }^{169}$ Bemis v. Minister for Arts, Heritage, Gaeltacht and the Islands [2007] 3 IR 255; Bemis v. Minister for Arts, Heritage, Gaeltacht and the Islands [2005] IEHC 207; Irish Independent, 'Lusitania telegraph machine lost during unsupervised dive' available at http://www.independent.ie/breaking-news/irish-news/lusitania-telegraph-machine-lost-duringunsupervised-dive-35494223.html; accessed 24 June 2017; Stolley (n 165).

${ }^{170}$ Operational Guidelines (n 12), at paras. 53 and 97.
} 
that sites have 'adequately delineated boundaries' ${ }^{171}$ This refers to one of the biggest challenges facing many UCH sites, raised earlier: the fact that several articles of the Convention, along with the Operational Guidelines, appear to require a territorial state to nominate and manage listed property. ${ }^{172}$

The jurisdiction and applicable law over UCH is a challenging area of law. Indeed, the international negotiations over the UCH Convention ended up unwittingly embroiled in a contentious political contest over the relative rights of flag, coastal and port states. ${ }^{173}$ Given powerful flag state fears over the creeping jurisdiction of coastal and port states - as had happened within UNCLOS III and within the 1985 Council of Europe exploring a new convention protecting $\mathrm{UCH}^{174}$ - the $\mathrm{UCH}$ Convention could not go beyond the firm allocation of state rights and responsibilities under the United Nations Convention on the Law of the Sea (LOSC). ${ }^{175}$ For UCH, therefore, the LOSC method of carving the oceans up into spatially defined 'zones' of state rights and responsibilities continues to govern. The unfortunate result is that the jurisdiction and law applicable to $\mathrm{UCH}$ remain entirely dependent upon its accidental geographical location.

Located just 11/2/2 nautical miles off the Head of Kinsale, the Lusitania wreck site falls under the exclusive jurisdiction of the Republic of Ireland. $\mathrm{UCH}$ located within the 12-nm territorial sea - and now, in accordance with many interpretations of Article 303(2) LOSC and Article 8 of the UCH Convention, also within the additional $12-\mathrm{nm}$ contiguous zone ${ }^{176}-$ can be regulated by the territorial state almost as if it were a monument on land. ${ }^{177}$ It would be for that territorial state to determine previous legal interests in the UCH (such as Bemis's ownership) and to govern those interests in accordance with its domestic law. The legal rules applicable to the Lusitania are therefore exclusively those of the Republic of Ireland - which is how the site receives additional protection under national heritage legislation. ${ }^{178}$ Yet, in accordance

\footnotetext{
171 Ibid., at para. 97; The site must also include a 'buffer zone' around it to ensure sufficient coverage (ibid., at paras. 103-107).

${ }^{172}$ See supra (nn 58, 62, 66 and 68).

${ }^{173}$ G Carducci, 'New Developments in the Law of the Sea: The UNESCO Convention on the Protection of Underwater Cultural Heritage', (2002), 96(2) The American Journal of International Law 419-434; M Rau, 'The UNESCO Convention on Underwater Cultural Heritage and the International Law of the Sea', (2002), 6(1) Max Planck Yearbook of United Nations Law 387-472.

${ }^{174}$ Council of Europe, Final Activity Report, Ad Hoc Committee of Experts on the Underwater Cultural Heritage (Strasbourg, 23 April 1985) Doc. CAHAQ (85)5; UNCLOS III referring to the negotiations over the United Nations Convention on the Law of the Sea (Montego Bay, 10 December 1982, in force 16 November 1994) 1833 UNTS 396 ("LOSC"); Dromgoole (n 3), at pp. 29-36 and 40-44.

${ }^{175} \mathrm{~S}$ Dromgoole, 'Reflections on the Position of the Major Maritime Powers with Respect to the UNESCO Convention on the Protection of the Underwater Cultural Heritage 2001', (2013), 38 Marine Policy 116-123; SD Murphy, 'U.S. Concerns Regarding UNESCO Convention on Underwater Heritage', (2002), 96(2) American Journal of International Law 468-470.

176 MJ Aznar, 'The Contiguous Zone as an Archaeological Maritime Zone', (2014), 29(1) International Journal of Marine and Coastal Law 1-51.

${ }^{177}$ Grisbadarna Case (Norway/Sweden), Permanent Court of Arbitration (23 October 1909), (1910) 4 American Journal of International Law 226-236, at p. 231, 'the maritime territory is an essential appurtenance of land territory'; Y Tanaka, The International Law of the Sea (2 ${ }^{\text {nd }}$ ed., Cambridge University Press, Cambridge, 2015), at pp. 85-86.

${ }^{178}$ See (nn 167-168).
} 
with the Universal Declaration of Human Rights ${ }^{179}$ and the European Convention of Human Rights, ${ }^{180}$ the Irish government also needs to respect Bemis's right to some private enjoyment of his legal property.

The Republic of Ireland has ratified the LOSC. ${ }^{181}$ It therefore also shares a general 'duty to protect objects of an archaeological and historical nature found at sea and [to] cooperate for this purpose.' ${ }^{182}$ Quite what this hortatory commitment even means and how enforceable it is, is highly debatable. ${ }^{183}$ It is precisely this normative ambiguity under the LOSC which led to the UCH Convention's development and, although Ireland is not yet a signatory to the UCH Convention, it has signalled its willingness to join imminently and already complies with the Annexed Rules Concerning Activities Directed at Underwater Cultural Heritage ("Annexed Rules"). ${ }^{184}$ Under LOSC Article 303(3), states are also permitted to continue upholding the laws and rules of salvage on objects of a historical nature. ${ }^{185}$ However, when joining the UCH Convention, Ireland would be bound by the stricter prohibitions on private-centred historical salvage under Article 4. This clause anticipates that states, through their 'competent authorities', will only authorise a proposed salvage when: the Convention's first option of in situ preservation has been thoroughly considered; the proposed salvage has been determined not to be commercially exploitative; and, furthermore, when the project is found to be in line with the broader conservation, research, recovery, restoration and curation values of the UCH Convention and its Annexed Rules. ${ }^{186}$ The Irish government already restricts some of Bemis's private

\footnotetext{
${ }^{179}$ UN General Assembly, Universal Declaration of Human Rights (Paris, 10 December 1948) 217 A(III), Art. 17(2).

${ }^{180}$ Council of Europe, Protocol to the Convention for the Protection of Human Rights and Fundamental Freedoms (Rome, 20 March 1952, in force 18 May 1954) ETS No.009, Art. 1.

181 Formally ratified on 21 June 1996 (For list of LOSC States Parties and details of notifications and ratifications, see United Nations Treaty Collections, 'United Nations Convention on the Law of the Sea' available at https://treaties.un.org/pages/ViewDetailsIII.aspx?src=TREATY\&mtdsg_no=XXI6\&chapter=21\&Temp=mtdsg3\&clang=_en; accessed 24 June 2017.

${ }^{182}$ LOSC (n 173), Art. 303(1).

183 L Caflisch, 'Submarine Antiquities and the International Law of the Sea', (1982), 13 Netherlands Yearbook of International Law 3-32, at p. 20, it is 'far too general and vague to have any significant normative content'; M Risvas, 'The Duty to Cooperate and the Protection of Underwater Cultural Heritage', (2013), 2(3) Cambridge Journal of International and Comparative Law 562-590, at p. 571, the duty is 'too general and too unclear'; RC Blumberg (2005), 'International Protection of Underwater Cultural Heritage', in MH Nordquist, JN Moore and K Fu (eds), Recent Developments in the Law of the Sea and China (Martinus Nijhoff, Leiden, 2005) 491-514, at p. 493, the duty is 'hortatory only'; c.f., T Scovazzi, 'The Protection of Underwater Cultural Heritage: Article 303 and the UNESCO Convention', in D Freestone, R Barnes and DM (eds), The Law of the Sea: Progress and Prospects (Oxford University Press, Oxford, 2006) 120-136, at p. 122.

${ }^{184} \mathrm{~S}$ Kirwan, 'Ireland and the UNESCO Convention on the Protection of the Underwater Cultural Heritage', (2010), 5(2) Journal of Maritime Archaeology 105-115; N O'Connor, 'Ireland' in S Dromgoole (ed), The Protection of the Underwater Cultural Heritage: National Perspectives in Light of the UNESCO Convention 2001 ( $2^{\text {nd }}$ ed., Koninklijke Brill NV, Leiden, 2006) 127-144; UCH Convention (n 1), Annex: Rules Concerning Activities Directed at Underwater Cultural Heritage ("Annexed Rules").

${ }^{185}$ Scovazzi (n 182), at pp. 125-126, refers to Article 303(3) as an 'invitation to looting'.

${ }^{186}$ O'Keefe (n 2), at p. 50; Dromgoole (n 3), at p. 61.
} 
exploitation of the site through national heritage legislation in such a manner, wherever possible. ${ }^{187}$

In summary, provided its owner agreed (see supra) and that the Irish government ratified the UCH Convention, the Lusitania site would be covered by a sufficiently replete and effective legal system to be listed as World Heritage in the form of Irish domestic law. ${ }^{188}$ Furthermore, Ireland would have little issue nominating the Lusitania as 'within its territory', as required by Articles 3, 4 and 11(3) of the World Heritage Convention.

The jurisdictional context for the Titanic wreck site, located 320 nautical miles south-southeast of Newfoundland and on Canada's continental slope, is vastly more challenging. Unfortunately, a detailed exposition of conflicting legal commentary in this area is beyond the principal focus of this paper. ${ }^{189}$ We need only examine if it is possible to overcome the implicit territoriality requirements of the World Heritage Convention. ${ }^{190}$ Furthermore, the need for a sufficiently intact regulatory and institutional system of protection, which can be explored in both this section and the following section looking at the conservation and management of the sites.

The three most important instruments in terms of the regulation of the Titanic are the LOSC, the UCH Convention and the International Titanic Agreement. The International Titanic Agreement, which provides for the long-term protection of the site as a memorial, was negotiated between the United States, United Kingdom, Canada and France between 1997 and 2000. ${ }^{191}$ However, as a result of the pressure from the United States-based commercial salvor, RMST, as well as the fact that both the United Kingdom and United States take legal approaches towards UCH which are arguably outmoded or controversial, the resulting agreement carries several defects. ${ }^{192}$ For example, it permits $R M S T$ to continue salvaging the debris field around the vessel. ${ }^{193}$ As a result, only the United Kingdom has so far joined the agreement. ${ }^{194}$ It will not even come into force until the United States, who signed 13 years ago, passes implementing legislation. ${ }^{195}$ It is also open for

\footnotetext{
${ }^{187}$ See (nn 167-168).

${ }^{188}$ For a more detailed exposition of UCH law in Ireland see: Kirwan (n 183) and O'Connor (n 183).

189 See, e.g., Aznar and Varmer (n 75) and Niemeyer (n 75).

${ }^{190}$ In fact, the World Heritage Convention (n 1) refers several times, in addition to Arts. 3, 4 and 11(3), to the role of the territorial state in the management and nomination of properties, e.g., Arts. 5, 6, 11(1), 11(8), 13(4) and 19.

${ }^{191}$ National Oceanic and Atmospheric Administration (n 158).

${ }^{192}$ E.g., International Titanic Agreement (n 157), Art. 3, 'Each Party shall take all reasonable measures to ensure that all artifacts recovered from RMS Titanic . . . under its jurisdiction, are conserved and curated consistent with the relevant Rules'.

193 International Titanic Agreement (ibid.), Art. 4(3); National Oceanic and Atmospheric Administration (n 158); Department for Transport (n 92), at para 2.6; C Blanco, 'Marine Environment', in S Hutt and D Tarler (eds), Yearbook of Cultural Property Law 2007 (Left Coast Press, Walnut Creek, 2007) 83-86, at p. 85.

194 The United Kingdom ratified the Agreement on 6 November 2003 (National Oceanic and Atmospheric Administration (n 158)) and implemented it through the Protection of Wrecks (RMS Titanic) Order 2003, SI 2003 (No. 2496).

195 R.M.S. Titanic Maritime Memorial Preservation Act of 2012, S.2279, $112^{\text {th }}$ Congress (2012).
} 
signature by all states worldwide. ${ }^{196}$ However, for reasons noted, it is unlikely to attract any further support. ${ }^{197}$

The most important instrument in the regulation of offshore UCH is the LOSC, being the principal agreement setting out state rights and responsibilities across the maritime zones. ${ }^{198}$ Most states who have an impact on the Titanic site (e.g., US, Russia and France), or currently have the potential to have an impact upon it (e.g., China and Japan), are signatories to the LOSC. ${ }^{199}$ Except for the United States, however, who although not a member, does recognise its customary nature. ${ }^{200}$ By contrast, among those states with any link to activities at the Titanic, only France is currently a member of the UCH Convention. ${ }^{201}$ All these states are therefore under the hortatory (and generally meaningless) agreement to cooperate under LOSC Article 303(1). They are also permitted, under what now appears like an archaic admission, to continue authorising the supposed 'salvage' of archaeological sites. ${ }^{202}$ Otherwise, the LOSC remains deleteriously silent. Thus, most states remain practically free to exploit $\mathrm{UCH}$ in ABNJ as if $\mathrm{UCH}$ were some common pool resource. ${ }^{203}$ The only other relevant Article in the LOSC is Article 149 which requires that any archaeological objects in the deep seabed (the 'Area') are 'preserved' or 'disposed of' for the benefit of mankind. ${ }^{204}$ As with Article 303, however, it is agreed that this clause is so ambiguous as to make it almost meaningless. ${ }^{205}$

\footnotetext{
196 International Titanic Agreement (n 157), Art. 11(1); O Varmer and MJ Aznar, 'The Centenary of Titanic and the Treaty Giving Legal Protection' in UNESCO Scientific Colloquium on Factors Impacting the Underwater Cultural Heritage, $10^{\text {th }}$ Anniversary of the Convention on the Protection of the Underwater Cultural Heritage (Royal Library of Belgium, Brussels, 13-14 December 2011), available at http://www.unesco.org/fileadmin/ MULTIMEDIA/HQ/CLT/pdf/UCH_Brussels_S1_Ole\&Aznar.pdf; accessed 25 June 2017), at p. 6, 'Of course, the more nations that become parties to the International Agreement, the better its protection will be.'

${ }^{197}$ E.g., The National Oceanic and Atmospheric Administration (n 158), 'Representatives of the United States ... have informed Japan, Russia, and other nations of the Agreement and of the United States' interest in having other nations join the Agreement. To date, however, this has not resulted in any negotiations.'

198 Principally because the LOSC (n 173) operates almost as a "constitution for the oceans". Furthermore, because the LOSC, as at the time of writing, has 168 States Parties (see List of LOSC States Parties at (n 180)).

${ }^{199}$ See List of LOSC States Parties (n 180).

${ }^{200}$ AC Smith, 'Note: Frozen Assets: Ownership of Arctic Mineral Rights Must be Resolved to Prevent the Really Cold War', (2011), 41(3) George Washington International Law Review 651-680, at p. 672, 'Even though the United States is not a party to the treaty, U.S. case law adopts and acquiesces to [sic] the provisions of the [LOSC] and treats them as customary international law. For example, in United States v. Alaska, the government noted that the United States "has not ratified [the LOSC], but has recognized that its baseline provisions reflect customary international law" (referring to United States v. Alaska 503 U.S. 569 (1992), at para. 588).

${ }^{201}$ See List of UCH Convention States Parties (n 36).

${ }^{202}$ LOSC (n 173), Art. 303(3); Scovazzi (n 182), at pp. 125-126.

203 Excepting any other bilateral or multilateral agreements entered into by states. For example, a significant treaty in this regard would be the European Convention on the Protection of the Archaeological Heritage (Revised) (Valletta, 16 January 1992; in force 25 May 1995) ETS No.143, which promotes the in situ preservation of archaeological sites and includes UCH within its purview (Art. 1(3)).

${ }^{204}$ LOSC (n 173), Art. 149

205 A Strati, 'Deep Seabed Cultural Property and the Common Heritage of Mankind', (1990), 40(4) International and Comparative Law Quarterly 859-894, at pp. 871-892; BH Oxman,
} 
Furthermore - although there was at one time uncertainty as to whether the Titanic wreck is located in the Area (meaning that Article 149 applies) or whether it will be included within Canada's outer continental shelf, as claimable under LOSC Article 76 - we now know affirmatively that it falls within Canada's claimed outer continental shelf. ${ }^{206}$ Sadly, the LOSC categorically failed to address UCH on the continental shelf. ${ }^{207}$ As a result, the failing governance model of disinterested flag-state supervision over a Grotian free-for-all continues to prevail. ${ }^{208}$ There are arguments that Canada could indirectly protect the Titanic by relying on its sovereign rights over 'natural resources' on the continental shelf, under Article 77, referring to the Titanic's unique biodiversity, ${ }^{209}$ or by regulating marine scientific research at

'Marine Archaeology and the International Law of the Sea', (1988), 12(3) Columbia VLA Journal of Law and the Arts 353-372, at p. 361; L Bautista, 'Ensuring the Preservation of Submerged Treasures for the Next Generation: The Protection of Underwater Cultural Heritage in International Law', in HN Scheiber and MS Kwon (eds), Securing the Ocean for the Next Generation: Papers from the Law of the Sea Institute, LOSI Conference Papers 2012, UC Berkeley-Korea Institute of Ocean Science and Technology Conference, Seoul, Korea, May 2012 (University of California, Berkeley, 2012), at p. 16; Caflisch (n 182), at p. 29; Scovazzi (n 182), at p. 124, says 'Article 149 appears rather vague in its content and devoid of sufficient detail'.

206 Calculated by cross-checking the coordinates submitted by Canada in its claim for an extended continental shelf (see, e.g., 'Partial Submission of Canada to the Commission on the Limits of the Continental Shelf regarding its continental shelf in the Atlantic Ocean Executive Summary' (Government of Canada, 2013) available at http://www.un.org/depts/los/clcs_new/submissions_files/can70_13/es_can_en.pdf; accessed 25 June 2017); Note, however, that although Canada's claim was lodged on 6 December 2014, the next stage is a formal presentation at a session of the Commission (see Division for Ocean Affairs and the Law of the Sea, 'Submissions to the Commission on the Limits of the Continental Shelf, pursuant to article 76, paragraph 8, of the United Nations Convention on the Law of the Sea of 10 December 1982' available at http://www.un.org/depts/los/clcs_new/ commission_submissions.htm; accessed 25 June 2017).

207 Scovazzi (n 182), at pp. 124-125, refers to the 'legal vacuum' regarding UCH on the continental shelf and in the EEZ; Risvas (n 182), at p. 582, later acknowledges a 'widespread consensus' that there remains a legal vacuum.

208 E.g., D Freestone, 'International Governance, Responsibility and Management of Areas Beyond National Jurisdiction', 27(2) International Journal of Marine and Coastal Law 191204; K M Gjerde, H Dotinga, S Hart, E J Molenaar, R Rayfuse and R Warner (eds), Regulatory and Governance Gaps in the International Regime for the Conservation and Sustainable Use of Marine Biodiversity in Areas Beyond National Jurisdiction (IUCN, Gland, 2008); High Seas Task Force, Closing the Net: Stopping Illegal Fishing on the High Seas (Governments of Australia, Canada, Chile, Namibia, New Zealand, and the United Kingdom, WWF, IUCN and the Earth Institute at Columbia University, 2006); F Orrego Vicuña, The Changing International Law of High Seas Fisheries (Cambridge University Press, Cambridge, 2009), at pp. 200-268; Regarding a 'Grotian' perspective on the law of the see, see, e.g., GR Russ and DC Zeller, 'From Mare Liberum to Mare Reservarum', (2003), 27(1) Marine Policy $75-78$.

${ }^{209}$ O'Keefe (n 2), at pp. 68-69; MJ Aznar, 'Legal Status of Sunken Warships "Revisited"', (2003), 9 Spanish Yearbook of International Law 61-101, at p. 86; Blumberg (n 182); L Bautista, 'Gaps, Issues and Prospects: International Law and the Protection of Underwater Cultural Heritage', (2005), 14 Dalhousie Journal of Legal Studies 57-89, at p. 77. Many authors also raise other rights of coastal states under the LOSC which could be similarly applied indirectly to the protection of $\mathrm{UCH}$, such as Art. 80, on the erection of structures, and Art. 81, on the control of drilling on the seabed (e.g., S Dromgoole, 'Revisiting the Relationship between Marine Scientific Research and the Underwater Cultural Heritage', (2010), 25(1) International Journal of Marine and Coastal Law 33-61, at pp. 39-40). 
the site, under Article $246 .^{210}$ However, such arguments carry questionable legal credibility and would provide only scant and fragmented regulatory control. $^{211}$

The UCH Convention was thus intended to address these glaring regulatory weaknesses in the protection of $\mathrm{UCH}$ in ABNJ. However, the intense pressure from powerful maritime states to prevent creeping jurisdiction resulted in the simple continuation of the LOSC's flag-state governance model within the UCH Convention. ${ }^{212}$ Positively, Article 10(2) reinforces the power of coastal states, like Canada, to "prohibit or authorize any activity directed at such heritage to prevent interference with its sovereign rights'. ${ }^{213}$ For many distinguished commentators this was seen as an 'innovative expansion' of the law. ${ }^{214}$ For example, Canada could create a possible claim that its natural resources, such as the Titanic's biodiversity, are being interfered with by visitors to the site. However, such an argument is very weak and highly uncertain. For example, although the Titanic's unique biodiversity is a form of natural resource foreseen under Article 77, the term 'natural resource' was specifically intended to exclude $\mathrm{UCH}^{215}$ Equally, 'visiting' the site is likely not causing 'interference' with Canada's sovereign right to 'exploit' the resources on the continental shelf. ${ }^{216}$ What is more, Article 10(2) must always be read in conjunction with Article 3, which affirms that the UCH Convention cannot override the 'rights, jurisdiction and duties of States' under the LOSC and that it must be interpreted in a manner consistent with the latter. ${ }^{217}$ There

${ }^{210}$ Ibid., Dromgoole; K Croff, 'The Underwater Cultural Heritage and Marine Scientific Research in the Exclusive Economic Zone', (2009), 43(1) Marine Technology Society Journal 93-100.

${ }^{211}$ Scovazzi (n 182), at p. 124; Dromgoole (ibid.), at pp. 39-40; AHA Soons, Marine Scientific Research and the Law of the Sea (Kluwer Law, Deventer, 1982), at p. 275; MJ Aznar, 'The Legal Protection of Underwater Cultural Heritage: Concerns and Proposals', in C Espósito, J Kraska, HN Scheiber and M Kwon (eds), Ocean Law and Policy: Twenty Years of Development Under the UNCLOS Regime (Brill Nijhoff, Leiden, 2016) 124-127, at pp. 140142.

${ }^{212}$ Carducci (n 172); Rau (n173); Dromgoole (n 174); Murphy (n 174).

${ }^{213}$ UCH Convention (n 1), Art. 10(2).

${ }^{214}$ Quote from Bautista (n 204), at p. 19; O’Keefe (n 2), at p. 69; Aznar (n 207), at p. 86; E.g., Dromgoole (n 3), at pp. 290-291, liberally interprets this ability to prohibit activities to 'prevent interference' with sovereign rights as a broad power to prevent all activities which could 'threaten' any coastal state rights in that zone.

215 When originally codifying the sovereign rights of coastal states over resources on the continental shelf, under the 1958 Convention on the Continental Shelf, the International Law Commission states that '[i]t is clearly understood that the rights in question do not cover objects such as wrecked ships and their cargoes (including bullion) lying on the seabed or covered by the sand of the subsoil' in UN General Assembly, Yearbook of the International Law Commission 1956, Volume II, Documents of the eighth session including the report of the Commission to the General Assembly (New York, November 1957) A/CN.4/SER.A/1956/Add.1, at p. 298; Also, see, e.g., views of the Japanese expert in UNESCO, Svnoptic Report of Comments on the Draft Convention on the Protection of the Underwater Cultural Heritage, Third Meeting of Governmental Experts to consider the draft Convention on the Protection of the Underwater Cultural Heritage, Paris, UNESCO Headquarters, 3 to 7 July 2000 (UNESCO, Paris, April 2000) CLT-2OOO/CONF.201/3, at p. 2.

216 The sovereign rights offered to coastal states under the LOSC (n 173) Art. 77(1) are restricted to being 'for the purpose of exploring [the continental shelf] and exploiting its natural resources'.

${ }^{217} \mathrm{Rau}$ (n 172), at pp. 431-432; Carducci (n 172), at p. 422. It is also noteworthy that the LOSC only permits states to intercept, board and inspect foreign vessels in the continental 
would, however, be many other benefits that would accrue to the Titanic site if more states were to join the UCH Convention. For example, the commitment among states to respect the principle of in situ preservation, as well as to the effective implementation and enforcement of the Annexed Rules. ${ }^{218}$ Furthermore, among much else, ${ }^{219}$ are included requirements to prohibit salvage activities for private gain, ${ }^{220}$ to prosecute traffickers of $\mathrm{UCH}$ objects, ${ }^{221}$ and to cooperate in archaeological research. ${ }^{222}$

Crucially, however, where the UCH Convention could make an important difference for a site like the Titanic, is through its introduction of a 'Coordinating State' system. For UCH on the continental shelf/EEZ (Articles $9 \& 10$ ) and in the Area (Articles $11 \& 12$ ), the Convention anticipates the appointment of a state who will effectively guide and steer negotiations between all states possessing a 'verifiable link' to the UCH and wishing to join negotiations over activities directed at the site. ${ }^{223}$ In the Area, the International Seabed Authority will be invited into the discussions and states will choose among themselves who should be appointed the Coordinating State. ${ }^{224}$ Were the Titanic in the Area, therefore, a suitable Coordinating State would have been the United Kingdom, which possesses perhaps the strongest 'link' to the vessel. ${ }^{225}$ However, for UCH on the continental shelf, the first choice for Coordinating State would be the coastal state, Canada. ${ }^{226}$

shelf/EEZ zones under very strictly defined circumstances, such as to ensure compliance with fisheries law (Article 73), when they have reasonable grounds for suspecting piracy (Article 105), or for slave trading, unauthorised broadcasting or sailing without a flag (Article 110) (see e.g., IA Shearer, 'Problems of Jurisdiction and Law Enforcement Against Delinquent Vessels', (1986), 35(2) International and Comparative Law Quarterly 320-343, at pp. 335336; J Mossop, The Continental Shelf Beyond 200 Nautical Miles: Rights and Responsibilities (Oxford University Press, Oxford, 2016), at pp. 204-215).

${ }^{218} \mathrm{UCH}$ Convention (n 1), Art. 2(5), 'The preservation in situ of underwater cultural heritage shall be considered as the first option'; Dromgoole (n 3), at p. 58, it is 'difficult to overstate' the significance of the Annexed Rules (n 183), which 'are not simply an integral part of the Convention in a technical sense; they are integral to its entire spirit and ethos.'

${ }^{219}$ See generally, O'Keefe (n 2).

${ }^{220}$ UCH Convention (n 1), Arts. 2(7) and 4; Annexed Rules (n 183), Rule 2.

${ }^{221}$ UCH Convention (n 1), Arts. 14-18.

222 Ibid., at Arts. 19 and 21.

${ }^{223}$ UCH Convention (n 1), Arts. 9(5) and 11(4), 'Any State Party may declare . . its interest in being consulted on how to ensure the effective protection of that underwater cultural heritage. Such declaration shall be based on a verifiable link, especially a cultural, historical or archaeological link, to the [UCH] concerned'. Discussions on identification of states with a 'verifiable link, especially a cultural, historical or archaeological link' are sadly beyond the focus of this paper.

${ }^{224} \mathrm{UCH}$ Convention (n 1), Art. 12(2). Although the Preamble refers to the belief that cooperation with other non-state actors and key international and non-governmental organisations is 'essential', there are no provisions in the Coordinating State regime to encourage such inclusive cooperation.

225 Given that she was British-flagged, built in Belfast, insured by a consortium of underwriters through Lloyd's of London, and her owners, the White Star Line, were registered in Britain. Additionally, the UK asserting itself as coordinating state could refer to the LOSC (n 173), Art. 149, which requires that states consider the preferential rights of the 'state of origin' for UCH in the Area.

${ }^{226}$ UCH Convention (n 1), Art. 10(3)(b). 
For the purposes of World Heritage listing, it is incredibly important to consider the role that Canada would be expected to have. ${ }^{227}$ Under Article $10(5),{ }^{228}$ Canada would be responsible for either 'implementing' or ensuring the implementation of all the protective measures agreed through inter-state negotiations, ${ }^{229}$ as well as for 'issuing authorisations' for activities stemming from such negotiations. ${ }^{230}$ Canada can also 'conduct any preliminary research' on the UCH to support these negotiations. ${ }^{231}$ Albeit always constrained to some extent within the delicate balance of rights and obligations of the LOSC, ${ }^{232}$ a Coordinating State is expected to use this role to 'act on behalf of all States Parties as a whole and not in its own interest. ${ }^{233}$ Hence, returning to the implicit need for a territorial state under the World Heritage Convention, it appears that Canada could likely possess necessary 'authority' to nominate the Titanic for listing. It is particularly noteworthy that the Committee has already adopted such a purposive interpretation of the territoriality requirement so as to accept listings of natural heritage sites in the EEZ. Here, despite the rights and responsibilities of coastal states being strictly controlled under a sui generis regime beyond territorial waters, ${ }^{234}$ the Committee has been satisfied that coastal states carry sufficient authority to regard heritage as within their 'territory' for the purposes of the Convention. ${ }^{235}$

Furthermore, it is not just UCH which has been affected by this outdated wording in the Convention. International discussions are already

\footnotetext{
${ }^{227}$ If Canada turned down the opportunity to coordinate under Article 10(3)(b), the United Kingdom might be a sensible choice to act as Coordinating State in the alternative; see (n 224).

${ }^{228}$ UCH Convention (n 1), Art. 10(5); identical provisions exist for the Area, under Art. 12(4).

${ }^{229}$ Ibid., at Art. 10(5)(a) and Art. 12(4)(a), 'The Coordinating State shall implement measures of protection which have been agreed by the consulting States'.

${ }^{230}$ Ibid., at Art. 10(5)(b) and Art. 12(4)(b), 'The Coordinating State shall issue all necessary authorizations for such agreed measures in conformity with the Rules'.

${ }^{231}$ Ibid., at Art. 10(5)(c) and Art. 12(5), 'The Coordinating State may conduct any necessary preliminary research on the underwater cultural heritage and shall issue all necessary authorizations therefor'.

${ }^{232}$ Ibid., at Art. 3.

${ }^{233}$ Ibid., at Art. 10(6); For UCH in the Area, this wording has been slightly tweaked to require that they 'act for the benefit of humanity as a whole, on behalf of all States Parties' [emphasis added]. This is because the LOSC (n 173), Art. 149, declares that UCH in the Area must 'be preserved or disposed of for the benefit of mankind as a whole'.

${ }^{234}$ RR Churchill and AV Lowe, The Law of the Sea ( $3^{\text {rd }}$ ed., Manchester University Press, Manchester, 1999), at p. 166, 'the EEZ must be regarded as a separate functional zone of a sui generis character'; U Leanza and MC Caracciolo, 'The Exclusive Economic Zone', in D Attard, M Fitzmaurice and NA Martínez Gutiérrez (eds), The IMLI Manual on International Maritime Law: Volume I: The Law of the Sea (Oxford University Press, Oxford, 2014), at p. 185 , the 'EEZ appears a sui generis zone, as a transition zone between the territorial sea and the high seas. There, the coastal State does not enjoy territorial sovereignty, but only sovereign rights over economic resources within it.'

235 E.g., UNESCO Would Heritage List, 'Phoenix Island Protected Area' available at http://whc.unesco.org/en/list/1325; accessed 26 June 2017; UNESCO World Heritage List, 'Papahānaumokuākea Marine National Monument' available at http://whc.unesco.org/en/list/1326; accessed 26 June 2017; Freestone et al. (n 26), at p. 50, suggest that it is the general rights of coastal states to protect the marine environment under the LOSC which give them this ability; However, less persuasively, Dux contends that it is through Art. 11(3) of the World Heritage Convention, which permits nomination of 'property situated in a territory, sovereignty or jurisdiction' claimed by more than one state, suggesting that the word 'jurisdiction' is interpreted to include the EEZ (T Dux, Specially Protected Marine Areas in the Exclusive Economic Zone (EEZ) (Lit Verlag, Berlin, 2011) at p. 239).
} 
taking place at the World Heritage Marine Programme on the best means to overcome this defect in the Convention so as to permit heritage sites in the high seas. ${ }^{236}$ In 2016, Freestone et al. published the three methods by which the Committee can resolve this: a formal agreement by the Committee to interpret the Convention in a contemporary context and acknowledging the Convention's preambular objectives to protect all the 'world's heritage'; an external implementing agreement, akin to the 1994 Implementing Agreement for Part XI of the LOSC; or an optional protocol to the Convention. ${ }^{237}$ It seems patently clear that the best option - avoiding lengthy and complex negotiations over a new implementing instrument or amendment - would be the Committee (or States Parties at a UNESCO General Conference) agreeing on how to interpret the Convention in a modern context. ${ }^{238}$ What is needed is a minor tweak, not a wholesale renegotiation. As Freestone says, '[i]t is difficult to imagine that the Convention's founders' farsighted vision of protection captured in the preamble would have intentionally excluded half the surface of the earth'. ${ }^{239}$ Article 11(3) also clearly shows that the negotiators anticipated properties from areas with overlapping jurisdictions, ${ }^{240}$ which has already created 34 'transboundary' sites on the World Heritage List. ${ }^{241}$

In summary, if Canada were to join the UCH Convention, then there is a strong argument that they could nominate the Titanic to the World Heritage List. $^{242}$ This could be done readily by the Committee adopting a purposive interpretation of the World Heritage Convention's various articles requiring territoriality, ${ }^{243}$ and by recognising the essential role of Coordinating States in implementing agreements and issuing authorisations under Articles 10 and 12 of the UCH Convention.

\footnotetext{
${ }^{236}$ Freestone et al. (n 26) have suggested that the following five Marine Protected Areas in the high seas could work towards world heritage status: Costa Rica Thermal Dome (Pacific Ocean), White Shark Café (Pacific Ocean), Sargasso Sea (Atlantic Ocean), Lost City Hydrothermal Field (Atlantic Ocean), and Atlantis Bank (Indian Ocean).

${ }^{237}$ Freestone et al. (n 26), at pp. 50-51.

${ }^{238}$ Ibid., at pp. 48-51; F Francioni, 'The 1972 World Heritage Convention: An Introduction' in F Francioni and F Lenzerini (eds), The 1972 World Heritage Convention: A Commentary (Oxford University Press, Oxford, 2008) 3-8, p. 6, 'The dynamic character of international law in the areas of natural and cultural heritage . . . has facilitated the development of interpretative criteria that permit the adaptation of existing law to new realities and risks.'

239 Freestone et al. (n 26), at p. 11, 'Nothing in the [World Heritage Convention's] inspirational vision suggests that natural or cultural heritage of OUV located in [ABNJ] should be excluded from this protection.' They stress that 'the time has indeed come to remedy this historical oversight.'

${ }^{240}$ Ibid., at p. 48; Dux (n 234), at p. 239; World Heritage Convention (n 1), Art. 11(3), 'The inclusion of a property situated in a territory, sovereignty or jurisdiction over which is claimed by more than one State shall in no way prejudice the rights of the parties to the dispute.'

241 UNESCO World Heritage List, 'Transboundary' available at whc.unesco.org/en/list/?\&transboundary=1; accessed 26 June 2017; A good example is the Wadden Sea, which is jointly managed by Netherlands, Denmark and Germany (UNESCO World Heritage List, 'Wadden Sea' available at http://whc.unesco.org/en/list/1314; accessed 26 June 2017); Operational Guidelines (n 12), at para. 135, 'It is highly recommended that the States Parties concerned establish a joint management committee or similar body to oversee the management of the whole of a transboundary property.'

242 This coincidentally assists previous proposals that requiring states to join the UCH Convention before being permitted to list $\mathrm{UCH}$ as world heritage could help promote membership of the UCH Convention (e.g., Khakzad (n 66), at pp. 7-8).

${ }^{243}$ Laffoley and Freestone (n 25), at p. 132, 'Under any scenario, a system for the protection of World Heritage sites in areas beyond national jurisdiction will need to be elaborated'.
} 


\section{UCH Integrity and Conservation Management}

It is difficult to completely detach matters of jurisdiction and conservation management. The predominance of the flag state regulatory model in ABNJ causes many challenges for the effective implementation of any multilateral conservation and management plan. ${ }^{244}$ Furthermore, even if the states who are most likely to have an impact upon a conservation area were signed up to the arrangement, there is no guarantee that they will effectively implement legislation or invest in its proper enforcement, ${ }^{245}$ or, furthermore, that flags or ports 'of convenience' will not undermine or free ride on the hard work of other states, ${ }^{246}$ or that policy and institutional fragmentation between regions and sectors will not create regulatory gaps. ${ }^{247}$ Such are the international difficulties with effectively regulating conservation arrangements in the high seas, that the United Nations is underway negotiating an international instrument to address this exact problem. ${ }^{248}$ Unfortunately, the instrument is at present concerned with high seas and deep seabed 'biodiversity' and not with cultural heritage. To make matters yet worse for $\mathrm{UCH}$, the categorical failure of the LOSC to address its protection technically renders its 'areas beyond national jurisdiction', where such regulatory and implementation challenges occur, not just the Area and high seas, but across the entire continental shelf and EEZ zones as well.

The result of this zonal differentiation will likely lead to the formation of different categories of offshore 'cultural' Marine Protected Areas (MPAs) enclosing and protecting specific UCH sites - depending on where the site is located. For sites in territorial waters or the contiguous zone (up to 24 nautical miles), like the Lusitania, this cultural protected area would essentially be

\footnotetext{
${ }^{244}$ See (n 207).

245 RG Rayfuse, Non-Flag State Enforcement in High Seas Fisheries (Martinus Nijhoff, Leiden, 2013), at pp. 36-37; S Borg, Conservation on the High Seas: Harmonizing International Regimes for the Sustainable Use of Living Resources (Edward Elgar Publishing, Cheltenham, 2012), at pp. 193-216; Global Ocean Commission, From Decline to Recovery A Rescue Package for the Global Ocean Global Ocean, Commission Report 2014 (Global Ocean Commission, Oxford, 2014), at pp. 7-8; MW Lodge, A Anderson, T Løbach, G Munro, K Sainsbury and A Willock (eds), Recommended Best Practices for Regional Fisheries Management Organisations (The Royal Institute of International Affairs, Chatham House, London, 2007), at pp. 44-69.

${ }^{246}$ D König, 'Flags of Convenience', in R Wolfrum (ed), The Max Planck Encyclopedia of Public International Law (Oxford University Press, Oxford, 2017), available at http://opil.ouplaw.com/home/EPIL; accessed 26 June 2017; T Shaughnessy and E Tobin, 'Flags of Inconvenience: Freedom and Insecurity on the High Seas', (2006), 5 University of Pennsylvania Journal of International Law \& Policy 1-31; CJ Goodman, 'The Regime for Flag State Responsibility in International Fisheries Law-Effective Fact, Creative Fiction, or Further Work Required', (2006), 23(2) Australia and New Zealand Maritime Law Journal 157-169; This has already happened with the Titanic when the United States introduced the Titanic Memorial Act 1986, after which US deep-sea diving experts simply began working with Russian and French companies (Ballard and Durbin (n 87), at p. 259).

247 Tanaka (n 30), at pp. 17-25; D Tladi, 'Ocean Governance: A Fragmented Regulatory Network', in P Jacquet, RK Pachauri and L Tubiana (eds), Oceans: The New Frontier (Teri Press, New Delhi, 2007) 99-110; AT Gutiérrez and S Morgan, 'Impediments to fisheries sustainability - Coordination between public and private fisheries governance systems', (2007), 135 Ocean \& Coastal Management 79-92.

${ }^{248}$ See (n 26).
} 
managed and policed by the coastal state (Ireland), ${ }^{249}$ with likely cooperation from regional neighbours and key stakeholders. For sites on the continental shelf or the high seas, however, such management plans would need to be developed under multilateral arrangements between relevant states, including key stakeholders and international organisations such as the International Seabed Authority, International Maritime Organization and neighbouring regional fisheries management or environmental organisations. ${ }^{250}$ Working from the UCH Convention, these cultural MPAs would, in their incipient stages at least, be led by a Coordinating State. The creation of such multilateral agreements between states in furthering the regulatory protection of $\mathrm{UCH}$ is thus unequivocally promoted by the $\operatorname{LOSC}^{251}$ and the UCH Convention. ${ }^{252}$

Importantly, within these agreements, states would be entirely free to negotiate their relative rights and responsibilities and to decide how specific areas could be monitored and rules enforced. ${ }^{253}$ States could therefore model their agreements on other successful offshore MPAs, ${ }^{254}$ for example, by using new technologies such as satellite, radar and Automatic Identification Systems. ${ }^{255}$ Or, as with several regional fisheries agreements, they could even set up portside measures, ${ }^{256}$ arrange for cooperation in data-sharing and enforcement, ${ }^{257}$ or allow signatory states to interdict and inspect each other's

\footnotetext{
249 See (n 176); UCH Convention (n 1), Art. 7(1), 'States Parties, in the exercise of their sovereignty, have the exclusive right to regulate and authorize activities directed at underwater cultural heritage in their internal waters, archipelagic waters and territorial sea'; UCH Convention, Art. 8, 'States Parties may regulate and authorize activities directed at underwater cultural heritage within their contiguous zone'; See Aznar (n 175) on UCH in the contiguous zone.

${ }^{250}$ Freestone et al. (n 25), at pp. 52-53.

${ }^{251}$ LOSC (n 173), Art. 303(4).

${ }^{252}$ UCH Convention (n 1), Art. 6, 'States Parties are encouraged to enter into bilateral, regional or other multilateral agreements or develop existing agreements, for the preservation of underwater cultural heritage'; Under the World Heritage Convention, the Operational Guidelines (n 12) also promote multilateral arrangements for properties where states have overlapping jurisdiction (at paras. 39-40 and 135).

${ }^{253}$ Ballard and Durbin (n 87), at p. 259.

254 E.g., F Douvere, World Heritage Marine Sites: Managing effectively the world's most iconic Marine Protected Areas (UNESCO, Paris, 2015); G Kelleher, Guidelines for Marine Protected Areas (IUCN, Gland, 1999); PD Goriup, Management of Marine Protected Areas: A Network Perspective (Wiley-Blackwell, Hoboken, 2017).

${ }^{255}$ D Kroodsma and B Sullivan, 'Protecting marine World Heritage from space', in R Casier and F Douvere (eds), The Future of the World Heritage Convention for Marine Conservation: Celebrating 10 years of the World Heritage Marine Programme (UNESCO, Paris, 2016) 3548; SD Brooke, TY Lim and JA Ardron, Surveillance and enforcement of remote maritime areas - Paper 1: surveillance technical options (Marine Conservation Biology Institute, Seattle, 2010), available at https://marine-conservation.org/media/filer_public/2011/09/19/ serma_tech-options_v12.pdf; accessed 26 June 2017.

${ }^{256}$ R Rayfuse, 'Regional Fisheries Management Organizations', in DR Rothwell, AG Oude Elferink, KN Scott and T Stephens (eds), The Oxford Handbook of the Law of the Sea (Oxford University Press, Oxford, 2015) 439-462, at p. 454; Orrego Vicuña (n 206), at pp. 256-266; EJ Molenaar, 'Port State Jurisdiction: Toward Comprehensive, Mandatory and Global Coverage', (2007), 38(1-2) Ocean Development \& International Law 225-257.

${ }^{257}$ Rayfuse, ibid., at pp. 447-448; Orrego Vicuña, ibid., at pp. 252-259; S Kaye, 'Enforcement Cooperation in Combating Illegal and Unauthorized Fishing: An Assessment of Contemporary Practice', (2014), 32(2) Berkeley Journal of International Law 316-329.
} 
vessels if they are found engaged in suspicious activity. ${ }^{258}$ The management and implementation of an offshore MPA around a site like the Titanic would not be easy, not least due to the logistical challenge of multi-dimensionally policing both the seabed and ocean surface above. However, if it is now possible to protect $286,200 \mathrm{~km}^{2}$ of the high seas of the North-East Atlantic via a network of MPAs under the OSPAR Convention, ${ }^{259}$ then why not a comparatively miniscule site like the Titanic ${ }^{260}$ In fact, the MS Estonia wreck already has, in some senses, such a cultural MPA arranged over Finland's continental shelf. ${ }^{261}$ Nine states have signed the multilateral agreement to guard the wreck as a protected gravesite in recognition of the 852 people who died in the shocking ferry disaster in $1994 .{ }^{262}$ This has also led to the site being blocked off by the Swedish Navy and being regularly monitored by Finnish Navy radar. ${ }^{263}$

Returning to the challenge of listing the Titanic on the World Heritage List, the Committee would expect a detailed breakdown of the long-term regulatory and institutional landscape under which the site would be effectively conserved, monitored and managed. ${ }^{264}$ The MPA would also need to demonstrate the 'full commitment' of signatory states towards the conservation of the Titanic ${ }^{265}$ and, more specifically, the protection its OUV

\footnotetext{
258 Rayfuse, ibid., at pp. 456-457; Orrego Vicuña, ibid., at pp. 245-251; A Norris, 'Fishy Business: The High Seas Boarding and Inspection Regime in the Western and Central Pacific Ocean', (2015), 46(4) Ocean Development \& International Law 331-344.

259 BC O’Leary, RL Brown, DE Johnson, H von Nordheim, J Ardron, T Packeiser and CM Roberts, 'The First Network of Marine Protected Areas (MPAs) in the High Seas: The Process, the Challenges and Where Next', (2012), 36(3) Marine Policy 598-605. Although not technically a MPA at the moment, it is also worth noting the growing inter-state agreement to collaborate in the protection of the Sargasso Sea area which is in excess of 4 million $\mathrm{km}^{2}$ (see D d'A Laffoley, H S J Roe, M V Angel, J Ardron, N R Bates, I L Boyd, S Brooke, K N Buck, C A Carslon, B Causey, M H Conte, S Christiansen, J Cleary, J Donnelly, S A Earle, R Edwards, K M Gjerde, S J Giovannoni, S Gulick, M Gollock, J Hallett, P Halpin, R Hanel, A Hemphill, R J Johnson, A H Knap, M W Lomas, S A McKenna, M J Miller, P I Ming, R Moffitt, N B Nelson, L Parson, A J Peters, J Pitt, P Rouja, J Roberts, J Roberts, D A Seigel, A N S Siuda, D K Steinberg, A Stevenson, V R Sumaila, W Swartz, S Thorrold, T M Trott and $\mathrm{V}$ Vats, The protection and management of the Sargasso Sea: The golden floating rainforest of the Atlantic Ocean. Summary Science and Supporting Evidence Case (Sargasso Sea Alliance, Washington DC, 2011), at p. 7, 'The Sargasso Sea study area occupies 4,163,499 $\mathrm{km}^{2}$ ').

${ }^{260}$ The Titanic's debris field has been estimated as $5.2 \mathrm{~km}^{2}$, per Rubin (n 133), which if you were to include a $1-\mathrm{km}$ 'buffer zone' around the site would create a protected zone of only $10.7 \mathrm{~km}^{2}$

261 Överenskommelse med Estland och Finland om m/s Estonia 1995: SÖ: 36 (Swedish Ministry for Foreign Affairs, Tallinn, 23 February 1995) [Agreement between the Republic of Estonia, the Republic of Finland and the Kingdom of Sweden regarding the M/S Estonia]; Wrecksite.eu, 'MV Estonia' available at http://wrecksite.eu/wreck.aspx?93755; accessed 26 June 2017.

${ }^{262}$ M Jacobsson and J Klabbers, 'Rest in Peace? New Developments Concerning the Wreck of the M/S Estonia', (2000), 69(3) Nordic Journal of International Law 317-332; K Takamaa and P Lunetta, (2013), 'Legal and Ethical Aspects Concerning Human Remains in Water and Burial at Sea' in J Bierens (ed), Drowning: Prevention, Rescue, Treatment $\left(2^{\text {nd }}\right.$ ed., Springer, Heidelberg, 2014) 1211-1217, at p. 1214.

263 Ibid.

${ }^{264}$ Operational Guidelines (n 12), at paras. 96-119; Freestone et al. (n 25), at p. 28.

265 Operational Guidelines (n 12), at para. 53.
} 
characteristics. $^{266}$ There is no question that this is achievable. ${ }^{267}$ Many existing offshore MPAs with World Heritage status cover vast tracts of seabed, protecting submarine features such as seamounts and benthic ecosystems. $^{268}$ Furthermore, several 'mixed heritage' marine sites already include UCH features as an element of protected OUV. ${ }^{269}$

One question is whether it would be prudent to use the International Titanic Agreement as a basis for the MPA or whether to negotiate an entirely new instrument. In truth, however, the International Titanic Agreement is likely to be quite unpopular as a result of its permissive stance over salvage activities by RMST. It is also likely tainted by its close connection with a state infamous for sanctioning treasure hunting on submerged archaeological sites. $^{270}$ The Agreement should thus be abandoned and, to attract the support of the global community and UNESCO, an entirely new international negotiation - inclusive of a far broader collective of states and stakeholders operating under guidance of the UCH Convention - should be commenced. A sticking point in these new negotiations is likely to include, therefore, the extant legal interest in the site asserted by RMST and the United States Virginian District Court. Many states might expect, understandably, that the United States first completely remove RMST's legal right to salvage the site. This would not be an entirely uncontentious negotiation for sure. ${ }^{271}$

The final prerequisite for listing on the World Heritage Convention is site integrity. ${ }^{272}$ This means the site needs to be a complete representation of the heritage, including all of its OUV elements, ${ }^{273}$ as well as relatively intact and free from neglect. ${ }^{274}$ Given that the OUV value of the sites is the archaeological nature of the wrecks themselves, which also indisputably represent the whole and true Titanic and Lusitania archaeological record, it seems that the requirement of representation and enclosure of OUV can be

\footnotetext{
${ }^{266} \mathrm{Ibid}$., at para. 108, 'Each nominated property should have an appropriate management plan . . . which must specify how the Outstanding Universal Value of a property should be preserved, preferably through participatory means'; Douvere (n 253), at p. 20.

${ }^{267}$ E.g., Speer and Casier note that the accepted need for an ecosystems approach in marine management will naturally 'result in the identification of . . . World Heritage sites that cross national boundaries' (L Speer and R Casier, 'Identifying candidate marine World Heritage sites in the Arctic', in R Casier and F Douvere (eds), The Future of the World Heritage Convention for Marine Conservation: Celebrating 10 Years of the World Heritage Marine Programme (UNESCO, Paris, 2016) 105-122, at p. 116).

${ }^{268}$ E.g., The Phoenix Islands Protected Area (n 234) covers $408,250 \mathrm{~km}^{2}$ and includes 'coral . . . ecosystems', 'underwater sea mounts . . . and other deep-sea habitats'; The Papahānaumokuākea Monument (n 234) covers $362,075 \mathrm{~km}^{2}$ and is made up of pelagic and deepwater habitats, with notable features such as seamounts and submerged banks, extensive coral reefs'; The Great Barrier Reef covers 348,700 $\mathrm{km}^{2}$ and includes thousands of coral reefs, as well as seascapes and associated fauna, with a depth range that extends 'beyond the continental shelf to oceanic waters over 2,000 metres deep' (UNESCO World Heritage List, 'Great Barrier Reef' available at http://whc.unesco.org/en/list/154; accessed 27 June 2017).

${ }^{269}$ See (nn 20-21).

${ }^{270}$ Forrest (n 162); Scovazzi (n 162).

${ }^{271}$ Questions would likely be asked about the future management of the 6,000 Titanic artefacts placed in pay-for-view museums and exhibitions across the United States (NR Orpen, 'Marine Environment' in S Hutt and D Tarler (eds), Yearbook of Cultural Property Law 2010 (Left Coast Press, Walnut Creek, 2010) 85-98, at p. 90).

272 The final aspect required in the Operational Guidelines (n 12) at para. 78 and elucidated in paras. 79-95.

273 Ibid., at paras. $79-86$.

${ }^{274} \mathrm{Ibid}$., at paras. 87-95; Obura and Bertzky (n 15), at p. 93.
} 
met. $^{275}$ A difficulty might arise, however, in that the Titanic and Lusitania sites are severely dilapidated and showing clear signs of neglect. ${ }^{276}$ Nevertheless, many run-down archaeological sites and monuments can become listed while a plan for their restoration is simultaneously launched. ${ }^{277}$ Better still, provided the restoration, conservation and management plan is launched first, before seeking World Heritage status, then the sites would no longer be in 'neglect'. The growing body of scientific expertise on the effective in situ conservation of UCH could therefore be used effectively to strengthen and endorse any restoration plan. ${ }^{278}$ If it is well designed and researched, has the backing of experts such as ICOMOS, provides a fair balance between the interests of stakeholders, and includes a thorough impact assessment adopting precautionary principles, then such a plan should be internationally endorsed. ${ }^{279}$ Thus, Ballard's plan to paint and preserve the Titanic is not science fiction, but could form a practical conservation measure within a broader international management plan for the site.

\section{Conclusion}

This paper has introduced and critically assessed the many legal and practical issues that UCH would face if put forward to the World Heritage List. What is particularly important to note is that universally valued wreck sites, such as the RMS Titanic and RMS Lusitania, have every opportunity of becoming listed. There is no question that such sites are not easily 'movable'. ${ }^{280}$ Nor is there any doubt that they possess OUV characteristics. ${ }^{281}$ The fact that they have potentially no owners, or several potential owners, is also in itself no obstacle to being listed. ${ }^{282}$ Furthermore, for all UCH located on the continental shelf or

\footnotetext{
${ }^{275}$ Marshall (n 118), at p. 63, for archaeological sites, 'authenticity is judged according to the ability of the archaeological remains to truthfully convey their meaning'; c.f., Jeffery (n 62), at p. 118, suggests that UCH sites which represent war graves might be no longer authentic once human remains have since disappeared. However, there is no clear justification for arguing that gravesites are only "gravesites" while human remains exist there.

276 See (nn 84-92 and 99-102).

277 Operational Guidelines (n 12), at para. 116, 'Where the intrinsic qualities of a property nominated are threatened by human action ... an action plan outlining the corrective measures required should be submitted with the nomination file'; e.g., The Cultural Landscape and Archaeological Remains of the Bamiyan Valley (available at http://whc.unesco.org/en/list/208; accessed 26 June 2017) were inscribed on the Heritage in Danger List in 2003 at the same time as their inscription on the World Heritage List; Operational Guidelines (n 12), at para. 90, 'it is recognized that no area is totally pristine and that all natural areas are in a dynamic state'.

${ }^{278}$ E.g., D Gregory and M Manders (eds), Best practices for locating, surveying, assessing, monitoring and preserving underwater archaeological sites, SASMAP Guideline Manual 2 (SASMAP Project, Amersfoort, 2015) available at http://www.icr.beniculturali.it/documenti/allegati/SASMAP\%20Guideline\%20Manual\%202.p df; accessed 27 June 2017; M Manders, R Oosting and W Brouwers, MACHU Final ReportManaging Cultural Heritage Underwater No. 3 (Educom Publishers BV, Rotterdam, 2009) available at http://www.machuproject.eu/documenten/MACHU_report_3.pdf; accessed 27 June 2017.

${ }^{279}$ Operating Guidelines (n 12), at paras. 108-119.

${ }^{280}$ See (nn 132-143).

${ }^{281}$ See (nn 103-126).

${ }^{282}$ See (nn 159-161).
} 
in the Area, it is imminently possible to overcome the implicit need for territoriality under the World Heritage Convention. This could be done by taking a purposive interpretation of the Convention, which would construe the role foreseen for Coordinating States under Articles 10(5) and 12(4) of the $\mathrm{UCH}$ Convention as including the authority to nominate territories to the List, $^{283}$ much as the Committee has already done in permitting World Heritage Sites in the EEZ beyond 'territorial' waters. ${ }^{284}$

The fact that such sites are in a dilapidated state is also no reason to ultimately reject them from the List. ${ }^{285}$ Provided a well-designed conservation plan is put in place, the sites can be effectively restored and conserved on an ongoing basis. ${ }^{286}$ The only difficulty may be in ensuring sufficient regulatory and institutional oversight. ${ }^{287}$ However, considering the growing list of vast offshore MPAs attaining World Heritage Status, ${ }^{288}$ there is no doubt whatsoever that this can be done. With such a 'cultural MPA', all the relevant states and non-state actors would agree to support the project's conservation aims and values, as well as its institutional, regulatory and management framework.

Turning back to our examples: the Lusitania could be listed tomorrow if the Irish government were to develop a dedicated conservation, protection and management plan. This would likely include cleaning up and cordoning off the site, in situ conservation work, as well as radar, satellite or video monitoring linked up to the coastguard. However, the main obstacle with such a proposal, other than the question of cost and incentivisation, ${ }^{289}$ would be the wreck's owner, who appears opposed to long-term meticulous conservation. ${ }^{290}$ Nevertheless, the Lusitania case study has provided us with very clear evidence that much of the world's UCH - the vast majority of which is found within 24 nautical miles of land - is eligible for nomination to the World Heritage List, provided that it satisfies the usual requirements of OUV, authenticity, integrity and site management.

The Titanic must also be cordoned off and given in situ conservation, management and monitoring. What is required, however, is a well-designed cultural MPA to be negotiated between key states and stakeholders. Such a

\footnotetext{
${ }^{283}$ See (nn 226-232 and 235-240).

${ }^{284}$ See (nn 233-234).

${ }^{285}$ See (nn 275-276).

${ }^{286}$ See (nn 277-278).

287 Supra (nn 190-225 and 243-270).

${ }^{288}$ E Osipova, 'Towards a Positive Outlook for Marine World Heritage' in R Casier and F Douvere (eds), The Future of the World Heritage Convention for Marine Conservation: Celebrating 10 Years of the World Heritage Marine Programme (UNESCO, Paris, 2016) 49. 56, at p.54; See (nn 266-268).

${ }^{289}$ H Huisman \& B van Os, 'Relax, Don't Do It: A Future for Archaeological Monitoring', (2016), 18(1-3) Archaeological Monitoring, Conservation and Management of Archaeological Sites 372-386, at p. 374. There are many persuasive arguments for why states might wish to preserve international cultural heritage on behalf of humanity (e.g., see UNESCO Convention on the Protection and Promotion of the Diversity of Cultural Expressions (Paris, 20 October 2005; in force 18 March 2007) 2440 UNTS 311, Preamble; C Sandis (ed), Cultural Heritage Ethics: Between Theory and Practice (Open Book Publishers, Cambridge, 2014)). Additional motivations for the Titanic could be the shared enjoyment of the site, including international research, income from sustainable tourism (distributed using equitable principles, such as under Part XI LOSC and its Implementing Agreement), photographic media, and virtual wreck tours or telepresence (also see generally, Firth (n 10) and Spennemman (n 62)). ${ }^{290}$ See (nn 164-168).
} 
thing is not fantasy thinking, considering the growing list of offshore natural heritage MPAs possessing sufficient legal and institutional coverage. ${ }^{291}$ It appears that a suitable country to initially institute these developments would be Canada. If it joined the UCH Convention, Canada could assume the role of Coordinating State over the Titanic under Article 10. The first port of call in such negotiations, however, would be to scrap the tainted International Titanic Agreement ${ }^{292}$ and to launch new international negotiations towards a more integrated, inclusive, visionary and conservation-minded MPA which finally protects the world's most beloved shipwreck for future generations.

\footnotetext{
291 See (n 287); Handwerk (n 123); Ballard has commented that he could raise the private funding to carry out a conservation plan provided political and legal support was in place.

292 See (nn 269-270); The International Titanic Agreement, itself based on the UCH Convention's Annexed Rules, could provide inspiration for the new negotiations.
} 